\title{
Cellular Uptake and Radio-sensitization Effect of Small Gold Nanoparticles in MCF-7 Breast Cancer Cells
}

Branislava Janic ${ }^{1}$, Fangchao Liư ${ }^{2}$, Kevin R Bobbitt ${ }^{3}$, Stephen L Brown ${ }^{1}$, Indrin J Chetty ${ }^{1}$, Guangzhao Mao ${ }^{2}$, Benjamin Movsas ${ }^{1}$ and Ning Wen ${ }^{1 *}$

${ }^{1}$ Radiation Oncology, Henry Ford Hospital, Detroit, MI, USA

${ }^{2}$ Department of Chemical Engineering and Materials Science, Wayne State University, Detroit, MI, USA

${ }^{3}$ Department of Public Health Sciences, Henry Ford Hospital, Detroit, MI, USA

\begin{abstract}
Gold nanoparticles (AuNPs) are shown to increase cancer cells sensitization to ionizing radiation. Theoretical models predicted that due to the differences in absorption coefficient between gold and soft tissue, maximum sensitization can be achieved at kilovoltage $(\mathrm{kV})$, with minimum to no effect at megavoltage (MV) range, which was indeed demonstrated by previous research on AuNPs radio-sensitization with $\mathrm{kV}$ radiation. However, AuNPs effect at MV energies is still not clear. Radio-sensitization depends on AuNPs' internalization by cancer cells that is in turn affected by AuNPs size. The purpose of this study was to explore, in vitro, radio sensitization potential of AuNPs of 4 and $14 \mathrm{~nm}$ size with clinically relevant MV, as well as kV photons in MCF7 breast cancer cell line. We investigated the differences in cellular uptake and intracellular localization between 4 and $14 \mathrm{~nm}$ AuNPs by transmission electron microscopy (TEM). We also examined the effect of these AuNPs on MCF7 cells response to irradiation by MTT analysis of cell proliferation, and flow cytometry analysis of H2AX phosphorylation as an indicator of DNA double strand breaks (DSBs). Our results demonstrated significant AuNPs cellular uptake and a selective, size dependent intracellular localization with $4 \mathrm{~nm}$ AuNPs mostly residing in cytoplasm and $14 \mathrm{~nm}$ in nucleus. Nanoparticles of both sizes sensitized MCF-7 breast cancer cells to radiation at both $\mathrm{kV}$ and MV energies, independent of particle size. Radio-sensitization was detected as an increase in radiation induced inhibition of cell proliferation and radiation induced DNA DSBs. This work provides valuable information for further exploring mechanisms of AuNPs radio-sensitization in cancer cell lines that may be important in designing and optimizing AuNPs based radiotherapies.
\end{abstract}

Keywords: Gold nanoparticles; Radio-sensitization; MCF7 cell line; Breast cancer

\section{Introduction}

Cancer is one of the leading causes of death worldwide. As estimated by American Cancer Society, in 2018, in United States only, there will be 1,7 million newly diagnosed cancer cases and over a third of these cancer patients will die, with breast cancer significantly contributing to these statistics [1]. In more than fifty percent of cancer patients ionizing radiation, together with chemotherapy and surgery, is an integral part of a comprehensive cancer treatment [2]. However, for many types of cancers radiation therapy is efficient only if used at high doses and this approach often results in toxicity to the surrounding normal tissue, causing early and late side effects that can reduce the quality of life in patients [3]. Since first documented in the late $19^{\text {th }}$ century, radiation-induced cytotoxicity has been a major limiting factor in maximizing deposited radiation doses to the cancer tissues, and as such a significant obstacle in cancer treatment planning [4]. Enhancing therapeutic ratio of radio-treatment, i.e., delivering higher doses of radiation to the tumor itself, while minimizing damage to the surrounding normal tissue, has achieved significant milestones over the last few years through development in Intensity Modulated Radiation Therapy and Volumetric Modulated Arc Therapy [5,6]. In addition, therapeutic ratio enhancement can be achieved by increasing the cancer cells sensitivity to irradiation; hence, radio-sensitizers as modulators of tumor response to irradiation has been an emerging field of research, with a particular focus on exploitation of nanoparticles $[7,8]$.

Nanoparticles (NPs) are 1-100 nm constructs with a tremendous diagnostic and therapeutic potential for various types of diseases. In recent decades many advances have been made in the field of nanoparticles research that lead to the development of a variety of nanostructures for biomedical use. Depending on the application that can span from disease diagnosis to targeted drug delivery, nanoparticles are constructed from different materials and in different forms such as polymeric, liposome based, dendrimers metals as well as hybrid. For example, liposome-polymeric hybrid nanoparticles showed promising use as immunotherapeutic agent with a potential application in noncancerous and cancerous diseases [9-13], while metal nanoparticles are more frequently explored as imaging and sensitizing probes enhancing radiation therapy [14]. Cancer research has been particularly interested in application of metal based nanoparticles for imaging, targeted drug delivery and radio sensitization in various cancers $[15,16]$. Metal based NPs can increase the radio sensitivity of cancer cells by increasing local radiation dose deposition using differential absorption coefficient of high atomic number material, compared to the soft tissue $[17,18]$. Among many metal NPs, gold NPs (AuNPs) have been proposed as particularly attractive radiosensitizers due to their unique physicochemical properties. It is well established that synthetic chemistry of colloidal AuNPs allows precise tailoring of particle size and shape for optimal tissue delivery [19] as well as surface functionality for bio-conjugation to drugs and agents that specifically target tumor cell [20]. Gold NPs can easily enter the systemic circulation and infiltrate tumor tissues, and once inside the tumor they enhance the irradiation effect [14]. In addition, they have low systemic clearance that together with well absorption, contributes

*Corresponding author: Ning Wen, Department of Radiation Oncology, Henry Ford Hospital, 2799 West Grand Blvd Detroit MI, 48202, USA, Tel: 3135981317; E-mail: nwen1@hfhs.org

Received: May 04, 2018; Accepted: May 11, 2018; Published: May 15, 2018

Citation: Janic B, Liu F, Bobbitt KR, Brown SL, Chetty IJ, et al. (2018) Cellular Uptake and Radio-sensitization Effect of Small Gold Nanoparticles in MCF-7 Breast Cancer Cells. J Nanomed Nanotechnol 9: 499. doi: 10.4172/2157-7439.1000499

Copyright: (c) 2018 Janic B, et al. This is an open-access article distributed under the terms of the Creative Commons Attribution License, which permits unrestricted use, distribution, and reproduction in any medium, provided the original author and source are credited. 
to an enhanced permeation and retention effect (EPR) [21,22]. It has also been demonstrated that NPs containing gold have higher dose enhancement compared to NPs containing other materials due to high atomic number $(Z)$ of gold that provides for a large photoelectric cross section and high probability of secondary electron production [23]. However, this photoelectric effect is most dominant at low, kilo voltage $(\mathrm{kV})$ energy levels at which it causes a significant increase in the absorbed dose $[24,25]$. Yet, with few exceptions, $\mathrm{kV}$ energies are rarely used in a clinical setting where for most radiotherapies megavoltage (MV) X-rays are necessary to provide proper dose deposition to deepseated tumors and avoid skin damage [26]. Theoretical predictions by previous studies based on Monte Carlo modeling indicated low dose enhancement with AuNP at MV energies due to the predominance of Compton Effect and pair electron production [27] and consequently a lack of radio-sensitization. Contrary to these predictions, several studies provided evidence on radio-sensitization by AuNP at clinically relevant MV energies. Jain et al. demonstrated radio-sensitization by AuNPs in breast cancer MDA-MB-231 cells using $160 \mathrm{kV}, 6 \mathrm{MV}$ and 15 MV energies [28]. Radio-sensitization effects of AuNP at $6 \mathrm{MV}$ was also shown in cancer cells of gastric [29] and cervical [30] origin, as well as in geometric model of tumor blood vessel endothelial cells [31]. These controversial, experimentally observed AuNP radio-sensitizing effects using MV energies may partially be explained by work in DNA plasmid models showing AuNP induced DNA damage by short range, low energy Auger electrons that can deposit high local doses in the vicinity of NP [32] and these electrons can be produced by ionizing radiation at $\mathrm{MV}$ energies as well. However, it is still not clear whether cytotoxicity observed at MV energies can be solely attributed to MV induced ionization events within the AuNPs, or factors such as direct chemical and/or biological AuNP interaction with cellular processes also play a role. Given that most previous in vitro studies have focused on AuNP radio-sensitizing properties at $6 \mathrm{MV}$ megavoltage energy (MV) and that $2.5 \mathrm{MV}$ energy has been introduced to imaging application while $10 \mathrm{M} \mathrm{V}$ has been used for treatment on TrueBeam Linear Accelerator (Varian Medical System, Palo Alto, CA), we explored the AuNP effects using 2.5 MV and 10 MV energies and benchmarked it against $160 \mathrm{kV}$.

Regardless of the underlying mechanisms, for radio-sensitization to take place, AuNPs have to be taken up by the cell. Translocation of AuNPs across the cell membrane can be achieved via passive translocation or active endocytosis [33], the later resulting in endosomal/lysosomal AuNP intracellular processing [34,35]. Nanoparticles smaller than $10 \mathrm{~nm}$ are more likely to be taken up by passive process, while the receptor mediated endocytic pathway is typical for the larger ones and is associated with a better cellular uptake $[33,36]$. Once inside the cells AuNPs are trapped inside the endo- and lysosomal vesicles with no free AuNPs within the cytosol or nucleus [34,37]. However, some reports indicated that that both, smaller and larger NPs can reside in nucleus or in cytosol as free particles as well $[38,39]$. Overall, the final intracellular localization is determined by AuNPs cell surface functionalization that in turn largely depends on NP size, shape, surface charge, ligand modification, NP aggregation as well as the cell type. In addition, all these variables can also profoundly affect AuNPs biodistribution and biocompatibility and have been studied by different investigators, often reporting inconclusive and controversial results. Larger size AuNPs, have been reported to be less efficient in penetrating and evenly distributing within the tumor tissue and are more readily captured by macrophages and accumulated in liver $[36,40]$. On the other hand, AuNPs smaller than $5 \mathrm{~nm}$ in size tend to be rapidly eliminated through kidneys [41] and are more toxic at the cellular level $[42,43]$. Still, currently, there is no consensus on the ideal, clinically relevant AuNP size. In the light of current knowledge, we opted for AuNPs of $4 \mathrm{~nm}$ and $14 \mathrm{~nm}$ in size, anticipating optimal cell uptake with minimal toxicity, while ensuring biocompatibility.

Radiation-induced cell damage involves oxidative stress as one of the main mechanisms that is facilitated through the production of reactive oxygen species (ROS) that can directly damage DNA or through oxidation of cell proteins and lipids and mitochondrial impairment, initiate apoptosis and necrosis [44]. The most lethal form of DNA damage, DNA double-strand breaks (DSB) can lead to cell cycle arrest, redistribution of DNA repair factors and apoptosis [45]. One of the first responses to double-strand DNA breaks is the phosphorylation of 139 Serine in histone $\mathrm{H} 2 \mathrm{AX}$, a DNA packaging protein important for the recruitment of DNA repair machinery, with the numbers of phosphorylated $\mathrm{H} 2 \mathrm{AX}$ molecules linearly increasing with the severity of the damage [46]. Enhancement of DNA DSBs has been indicated as a possible mechanism in AuNP induced radio sensitization by studies where phosphorylation of histone $\mathrm{H} 2 \mathrm{AX}$ was used as an assessment of DNA damage [47].

Given the body of evidence on therapeutic potential of AuNP in clinically relevant settings the purpose of this study was to explore, in vitro, radio sensitization potential of AuNPs of 4 and $14 \mathrm{~nm}$ sizes with clinically relevant MV photons in MCF-7 breast cancer cell line. We chose the $4 \mathrm{~nm}$ and $14 \mathrm{~nm}$ core size because they are within the size range of suggested optimums for most efficient cellular uptake, accumulation and distribution within the tumors [48] and least possibility for cellular and systemic toxicity [49]. We investigated the differences in cellular uptake and intracellular localization between 4 and $14 \mathrm{~nm}$ AuNP by transmission electron microscopy (TEM). We also examined the effect of these AuNPs on MCF-7 cells response to irradiation by analyzing cell proliferation using MTT assay, and H2AX phosphorylation as an indicator of DNA DSBs by flow cytometry.

\section{Materials and Methods}

\section{Gold nanoparticle (AuNP) synthesis and characterization}

Materials: Gold (III) chloride trihydrate $\left(\mathrm{HAuCl}_{4} \cdot 3 \mathrm{H}_{2} \mathrm{O}, 99 \%\right.$ metal trace), sodium citrate tribasic dehydrate $(\geq 99 \%)$, mercaptosuccinic acid (MSA, 97\%), and sodium borohydride $\left(\mathrm{NaBH}_{4}, 98 \%\right)$ were all purchased from Sigma-Aldrich. Sodium hydroxide $(\mathrm{NaOH}, 98 \%)$ was purchased from Fisher Scientific.

AuNP synthesis: MSA coated AuNP4 (AuNP with diameter of 4 $\mathrm{nm}$ ) was synthesized following a modified method previously reported by our group [50]. The synthesis process started with a $250 \mathrm{ml}$ scale reaction that involved a mixture of $0.25 \times 10^{-3} \mathrm{M} \mathrm{HAuCl}_{4} \cdot 3 \mathrm{H}_{2} \mathrm{O}$ and $0.25 \times 10^{-3} \mathrm{M}$ tri-sodium citrate dissolved in deionized water vigorously stirred at room temperature. Addition of $7.5 \mathrm{~mL}$ ice cold $0.1 \mathrm{M} \mathrm{NaBH}_{4}$ solution changed the color of the solution into wine-red. After $30 \mathrm{~min}$ of stirring, $25 \mathrm{mg}$ of MSA was added after adjusting the $\mathrm{pH}$ of solution to 11 , using $0.1 \mathrm{M} \mathrm{NaOH}$ solution. To ensure complete ligand exchange the solution was continuously stirred for overnight. The solution was then purified and concentrated by centrifugation, using MW10K Millipore Amicon centrifugal columns, to the final concentration of $2 \mathrm{mg} / \mathrm{ml}$. MSA coated AuNP14 (AuNP with diameter of $14 \mathrm{~nm}$ ) was synthesized following the Turkevich method [51-54]. In a typical $250 \mathrm{ml}$ scale reaction, $0.25 \times 10^{-3} \mathrm{M} \mathrm{HAuCl}_{4} \cdot 3 \mathrm{H}_{2} \mathrm{O}$ was dissolved in deionized water and then heated to boil under vigorous stirring. Preheated $87.5 \mathrm{mg}$ of trisodium citrate dissolved in $15 \mathrm{~mL}$ deionized water was then added to the solution. After the color changed to winered, heating was continued for $25 \mathrm{~min}$ while stirring. Solution was then 
cooled down, the $\mathrm{pH}$ of solution was adjusted to 11 and $25 \mathrm{mg}$ of MSA added. Solution was then stirred overnight to ensure the complete ligand exchange. MW10 K Millipore Amicon centrifugal columns were used to purify and concentrate the solution after the reaction was done. The final concentration was $2 \mathrm{mg} / \mathrm{ml}$.

AuNP characterization: Upon completion of AuNPs synthesis, NPs were analyzed using JEOL JEM-2010 Transmission Electron Microscope (TEM) at the voltage of $200 \mathrm{kV}$ and current of $109 \mathrm{~mA}$. Energy dispersive $\mathrm{x}$-ray analysis (EDXA) spectrum was acquired on EDAX PV9756/70 ME EDS system attached to the TEM. The samples were prepared by applying a droplet of AuNP solution on a Formvarcoated copper grid. The averaged particle size was determined by measuring at least 50 particles. Dynamic light scattering (DLS) and zeta potential measurements were performed using a Malvern Nano-ZS. A $1 \mathrm{~mL}$ solution was transferred to a $2.0 \mathrm{~mL}$ polystyrene cuvette. The $\mathrm{Z}$-average hydrodynamic diameter (HD), polydispersity index (PDI), and zeta potential were measured at $25^{\circ} \mathrm{C} .15$ scans were performed in each measurement. The backscattering angle $\Theta$ was fixed at $172^{\circ}$ with a laser wavelength $\lambda=633 \mathrm{~nm}$. The size measurement range was set between $1 \mathrm{~nm}$ and $6 \mu \mathrm{m}$. HD is a function of the diffusion coefficient (D), temperature (T), and viscosity $(\eta)$ according to the StokesEinstein equation: $\mathrm{HD}=\frac{k T}{3 \pi \eta \mathrm{D}}$, where $\mathrm{k}$ is Boltzmann constant, $\mathrm{T}$ is room temperature $\left(25^{\circ} \mathrm{C}\right)$, and $\mathrm{D}$ was obtained from autocorrelation function via the cumulant fitting. The electrophoretic mobility of the nanoparticles was measured using the laser Doppler velocimetry and phase analysis light scattering technique of the Malvern Zetasizer. The electrophoretic mobility was converted into zeta potential by Smoluchowski equation, using the Malvern software [55]. Chemical composition of AuNPs was determined by thermogravimetric analysis (TGA) that was performed on TGA-Q50 instrument (TA company), using air as the working gas with the temperature range of $100-800^{\circ} \mathrm{C}$ and a heating rate of $10^{\circ} \mathrm{C} / \mathrm{min}$.

MCF-7 cell culture: MCF-7 breast cancer cells were cultured in high glucose Dulbecco's modified Eagle's medium (Gibco, MD) supplemented with $10 \%$ fetal bovine serum and 5\% penicillinstreptomycin (Invitrogen). Cells were maintained in a tissue culture incubator at $37^{\circ} \mathrm{C}$ with $5 \% \mathrm{CO}_{2}$. Cells were passaged every 3-4 days.

Cell exposure to nanoparticles: Twenty four hours prior to the exposure to AuNPs, MCF-7 cells were plated in 96 or 6 well cell culture dishes with total of $3 \times 10^{3}$ or $3-5 \times 10^{5}$ cells per well, respectively. Cells were cultured $\mathrm{o} / \mathrm{n}$ in a tissue culture incubator at $37^{\circ} \mathrm{C}$ with $5 \% \mathrm{CO}_{2}$, The next day cell were treated for 3 hours with either 4 or $14 \mathrm{~nm}$ AuNPs, diluted at various concentrations in a complete growth media. Four nm size AuNP was added at the concentrations of $3.9 \times 10^{12}$ particles per $\mathrm{ml}(\mathrm{p} / \mathrm{ml}), 7.8 \times 10^{12} \mathrm{p} / \mathrm{ml}, 1.56 \times 10^{13} \mathrm{p} / \mathrm{ml}$ or $3.12 \times 10^{13} \mathrm{p} / \mathrm{ml}$, while $14 \mathrm{~nm}$ size AuNP was used at $9 \times 10^{10} \mathrm{p} / \mathrm{ml}, 1.8 \times 10^{11} \mathrm{p} / \mathrm{ml}, 3.6 \times 10^{11}$ $\mathrm{p} / \mathrm{ml}$ or $7.2 \times 10^{11} \mathrm{p} / \mathrm{ml}$

Cell irradiation: The cells were irradiated with $2 \mathrm{~Gy}, 4 \mathrm{~Gy}$ and 8 Gy at set energies: $160 \mathrm{kV}, 2.5$ flattening filter free (FFF) MV (60 MU/min) or $10 \mathrm{FFF}$ MV (2400 MU/min) x-rays. The irradiation at MV energies was performed using linear accelerator (Varian, Palo Alto, Ca), while for $160 \mathrm{kV}$ energy we used Faxitron $160 \mathrm{kV}$ x-ray source (Wheeling, WV).

\section{Analysis of AuNP cellular uptake by transmission electron microscopy (tem) and inductively coupled plasma mass spectrometry (ICP-MS)}

A total of $5 \times 10^{5}$ cells were plated in 6 well cell culture plates and cultured for 24 h. Cells were then exposed for 3 hours to AuNPs. Four $\mathrm{nm}$ size AuNPs were added at the concentrations of $3.9 \times 10^{12} \mathrm{p} / \mathrm{ml}$ or $3.12 \times 10^{13} \mathrm{p} / \mathrm{ml}$, while $14 \mathrm{~nm}$ size AuNPs were used at $9 \times 10^{10} \mathrm{p} / \mathrm{ml}$ or $7.2 \times 10^{11} \mathrm{p} / \mathrm{ml}$. Following exposure, cells were washed twice in $1 \times$ phosphate-buffered saline (PBS), and prepared for TEM as previously described [50]. In brief, cells were fixed in in $2.5 \%$ glutaraldehyde in 0.1 M Phosphate Buffer, pH 7.4 (Electron Microscopy Sciences, Hatfield, PA) for 1 hour at room temperature. Cells were then scraped of the plates, centrifuged at a low speed and suspended in $2.5 \%$ glutaraldehyde. Samples were further processed at the Michigan State University (MSU) Center for Advanced Microscopy by post-fixation in 1\% osmium tetroxide, rinsing in distilled water, and dehydration through a graded series of acetone. At the end samples were embedded in epoxy resin and cut into $70 \mathrm{~nm}$ sections that were then analyzed and photographed by JEOL 100CXII electron microscope. For ICP-MS analysis cell pellets were first digested by $1 \mathrm{ml}$ of aqua regia $(0.75 \mathrm{ml}$ hydrochloric acid $(\mathrm{HCl})$ and $0.25 \mathrm{ml}$ nitric acid $\left.\left(\mathrm{HNO}_{3}\right)\right)$. The concentration of gold metal in digested cells was analyzed using an Agilent 7700x ICP-MS with an Agilent ASX-500 Series Autosampler. Prior to the analysis, external calibration using a series of standards with an internal standard correction of bismuth (Bi) was performed. Standards were purchased from High Purity Standards (Charleston, SC). To prevent precipitation or gold onto the surfaces of the instrument a rinse solution of $2 \% \mathrm{HCl}$ $(\mathrm{v} / \mathrm{v})$ was used. Saline blank solution was used as a negative control. Total amount of gold determined in each sample was used to calculate the total amount of gold per cell. The number of nanoparticles per cell was calculated by dividing the total amount of gold per cell by the known mass of a single AuNP.

Proliferation assay: Prior to the experiment, MCF-7 cells were grown to $75 \%$ confluence after which they were plated in 96 well plates, 3000 cells per well in 100 ul of complete DMEM growth media. Twenty four hours later, growth media was replenished and $4 \mathrm{~nm}$ or $14 \mathrm{~nm}$ AuNPs were added to the cells. Cells were incubated with the AuNPs for $3 \mathrm{~h}$ after which cell were exposed to $4 \mathrm{~Gy} \mathrm{X}$-ray irradiation using different energies. Immediately after irradiation, culture media containing AuNPs was removed. Cells were washed once with $200 \mathrm{ul}$ per well of 1x PBS and $100 \mathrm{ul}$ of fresh complete growth media was added to each well. Cells were then allowed to grow under normal culture conditions $\left(37^{\circ} \mathrm{C}, 5 \% \mathrm{CO}_{2}\right)$ for 7 days after which cell proliferation was analyzed by 3-(4,5-dimethylthiazol-2-yl)-2,5-diphenyltetrazolium bromide (MTT) assay as previously described [56]. In brief, $20 \mathrm{ul} \mathrm{per}$ well of MTT reagent (Roche Molecular Biochemicals, Indianapolis, IN) were added to the cells. After $2 \mathrm{~h}$ of incubation, the media containing MTT reagent was removed and cells were lysed by adding $100 \mathrm{ul} \mathrm{per}$ well of DMSO. MTT incorporation was determined by absorbance at $570 \mathrm{~nm}$ using the plate reader. All MTT assays were performed in 12 well replicates in each experiment, and results were normalized to untreated controls. The experiment was repeated 3 times.

Flow cytometry analysis of H2A.Xp: A total of $5 \times 10^{5}$ cells were plated in 6 well cell culture plates and cultured for $24 \mathrm{~h}$. Cells were then exposed for 3 hours to 4 and $14 \mathrm{~nm}$ AuNPs at the concentration of $3.12 \times 10^{13} \mathrm{p} / \mathrm{ml}$ and $7.2 \times 10^{11} \mathrm{p} / \mathrm{ml}$ respectively. Cells were then irradiated with $2 \mathrm{~Gy}, 4 \mathrm{~Gy}$ and $8 \mathrm{~Gy}$ at $160 \mathrm{kV}$ using a Faxitron 160 $\mathrm{kV} \mathrm{X}$-ray source, or at 2.5 FFF MV and $10 \mathrm{FFF}$ MV energies using Varian Edge linear accelerator. After irradiation cells were allowed to equilibrate for $30 \mathrm{~min}$ at $37^{\circ} \mathrm{C}, 5 \% \mathrm{CO}_{2}$. Cells were then washed with $1 \times$ PBS, detached from the plates using cell detachment Accutase solution (Biolegend, San Diego, Ca) and fixed by adding ice cold $70 \%$ ethanol in a drop wise fashion, while gently vortexing. Fixation was performed overnight at $-20^{\circ} \mathrm{C}$. The next day cells were washed in Cell Staining 
Citation: Janic B, Liu F, Bobbitt KR, Brown SL, Chetty IJ, et al. (2018) Cellular Uptake and Radio-sensitization Effect of Small Gold Nanoparticles in MCF-7 Breast Cancer Cells. J Nanomed Nanotechnol 9: 499. doi: 10.4172/2157-7439.1000499

Page 4 of 13

Buffer (Biolegend, San Diego, CA) and incubated in 2\% mouse serum for 30 minutes on ice, to block the nonspecific binding sites. Cell were then incubated with 4 ul per sample of FITC conjugated anti-human anti-H2A.X Phospho (Ser139) Mouse $\kappa$ IgG1 or corresponding Mouse к IgG1 isotype control antibody (Biolegend, San Diego, CA), on ice, in dark, for 1 hour. Cells were then washed $2 \mathrm{x}$ in staining buffer and the percent of cells positive for $\gamma \mathrm{H} 2 \mathrm{AX}$ was determined using an LSRII flow cytometer (BD Biosciences, San Jose, CA). A total of 100,000 events was acquired per sample. Data was analyzed using FACSDiva software v 8.0.1 (BD Biosciences). A live cell gate was created using the light scatter properties of the cells by plotting forward scatter (FSC; cell size) vs. side scatter (SSC; cell granularity). Cells from the live cell gate were subsequently analyzed for total $\gamma \mathrm{H} 2 \mathrm{AX}$ (gate P1) and additionally gated to identify a subpopulations exhibiting intense (gate P2) or moderate (gate P3) changes in fluorescence intensity.

Data analysis: Data was analyzed using GraphPad Prism by performing the unpaired Student $\mathrm{t}$-Test with Sidak-Bonferroni correction. Significance was set at the p value of 0.05 .

\section{Results}

\section{AuNP characterization}

Gold nanoparticles were characterized by TEM with energydispersive spectroscopy (EDAX), DLS and TGA. Images of synthesized AuNPs obtained by TEM were shown in Figure 1A. Diameters of AuNPs were determined to be $4.02 \pm 0.51 \mathrm{~nm}$ and $14.57 \pm 1.11 \mathrm{~nm}$ by performing at least 50 measurements per size batch $(\mathrm{N}=50)$. Nanoparticle chemical composition was further analyzed by EDAX that detected a peak at $2.120 \mathrm{eV}$ in both, $4 \mathrm{~nm}$ and $14 \mathrm{~nm}$ AuNPs, confirming the presence of gold in the particles (Figure 1B). The hydrodynamic sizes of AuNPs were measured by DLS in ambient conditions and the results showed that $4 \mathrm{~nm}$ AuNP and $14 \mathrm{~nm}$ AuNP diameters were $4.2 \mathrm{~nm}$ and $18.7 \mathrm{~nm}$, respectively (Figure 1C). Number based size distribution is weighted towards smaller particles while weight based distribution is weighted towards larger particles. We therefore opted to report number based distribution. As our nanoparticles were relatively uniform in size, we did not expect significant difference between these two numbers. Sizes measured by DLS are generally larger than those shown by TEM due to the inclusion of the MSA and solvent layer. To quantify the AuNPs chemical composition, TGA analysis was performed showing the weight loss of $8.61 \%$ for $4 \mathrm{~nm} \mathrm{AuNP}$ and $6.41 \%$ for $14 \mathrm{~nm}$ AuNP (Figure 1D), indicating that $4 \mathrm{~nm}$ AuNP coating contained 248 MSA molecules while $14 \mathrm{~nm}$ AuNP coating contained 8584 MSA molecules. The calculation was presented in the Supplementary Material (S1).

\section{AuNP uptake by MCF-7 cells}

Radio-sensitizing potential of AuNPs strongly depends on their uptake by the cells. This internalization of AuNPs can be achieved via passive translocation across the cell membrane or through active endocytosis [33] and may be affected by variables such as nanoparticle size, shape, surface chemistry and dose [57]. We analyzed the uptake of $4 \mathrm{~nm}$ AuNPs and $14 \mathrm{~nm}$ AuNPs by the MCF-7 breast cancer cells by measuring the amount of $\mathrm{Au}$ inside the cells using inductively coupled plasma mass spectrometry (ICP-MS). We used two different concentrations, "low" and "high", for both $4 \mathrm{~nm}$ and $14 \mathrm{~nm}$ AuNPs. Cells were incubated with $4 \mathrm{~nm}$ AuNP at the concentration of $3.9 \times 10^{12}$ $\mathrm{p} / \mathrm{ml}$ ("low") or $3.12 \times 10^{13} \mathrm{p} / \mathrm{ml}$ ("high"), and with $14 \mathrm{~nm}$ AuNP at the concentration of $9 \times 10^{10} \mathrm{p} / \mathrm{ml}$ ("low") or $7.2 \times 10^{11} \mathrm{p} / \mathrm{ml}$ ("high"). After 3 hours of incubation with AuNPs, cells were extensively washed to remove excess or any surface-attached nanoparticles. Cell pellets were
A

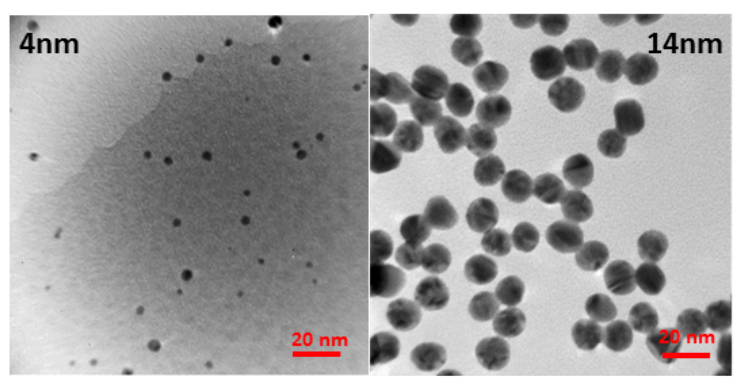

C

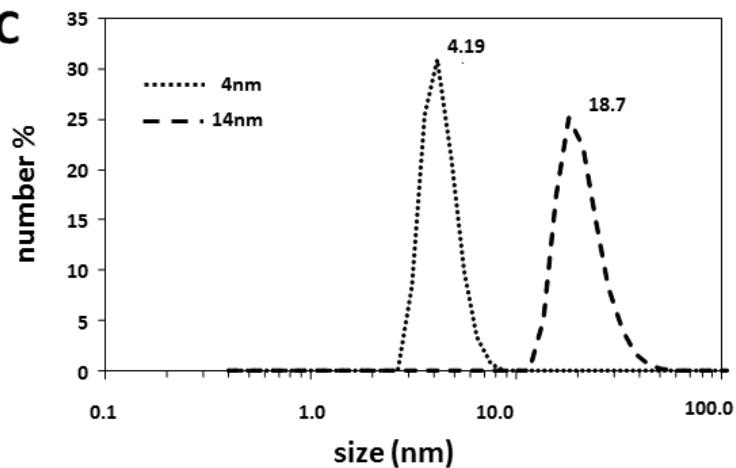

B

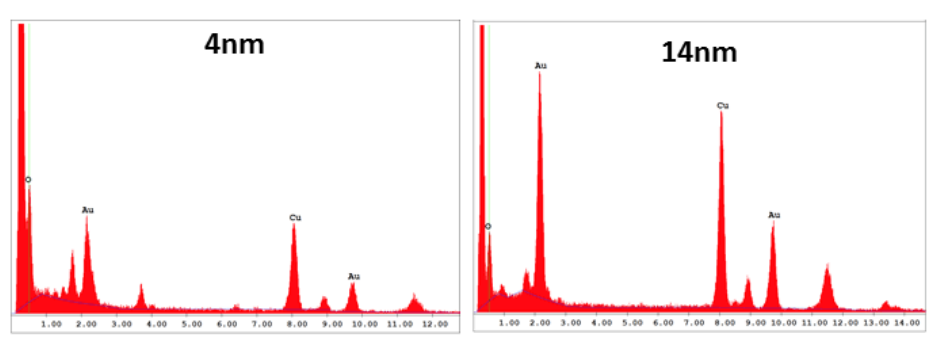

D

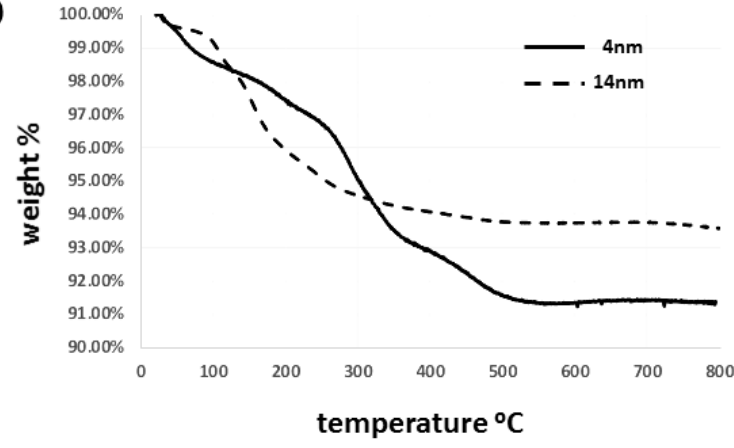

Figure 1: Characterization of gold nanoparticles. A) Transmission electron microscopic (TEM) images of AuNPs of averaged diameter $4 \mathrm{~nm}$ (right) and $14 \mathrm{~nm}$ (left). Scale bar=20 nm. B) Energy-dispersive spectroscopy (EDAX) analysis detected a peak at $2.120 \mathrm{eV}$ in $4 \mathrm{~nm}$ (left) and $14 \mathrm{~nm}$ (right) AuNPs, confirming the presence of gold in nanoparticles. C) Dynamic light scattering (DLS) spectra showing particle sizes of $4.19 \mathrm{~nm}$ and $18.7 \mathrm{~nm}$ corresponding to $4 \mathrm{~nm}$ AuNPs and $14 \mathrm{~nm}$ AuNPs, respectively D) Thermogravimetric analysis TGA quantification of AuNPs chemical composition showing the weight loss of $8.61 \%$ for 4 nm AuNP and $6.41 \%$ for 14 nmAuNP due to the presence of MSA surface coating. 
Citation: Janic B, Liu F, Bobbitt KR, Brown SL, Chetty IJ, et al. (2018) Cellular Uptake and Radio-sensitization Effect of Small Gold Nanoparticles in MCF-7 Breast Cancer Cells. J Nanomed Nanotechnol 9: 499. doi: 10.4172/2157-7439.1000499

subjected to ICP-MS to determine the total amount of intracellular gold (Figure 2A, left panel). This data was further analyzed to quantify the amount of gold per cell and numbers of nanoparticle uptake per cell (Figure 2A, right panel). A dose- dependent cellular intake was observed, with the "high" AuNP concentrations ensuring higher amount of total intracellular Au as well as higher numbers of AuNPs per cell, as compared to the "low" concentrations of both sizes of AuNPs used. In addition, $14 \mathrm{~nm}$ size AuNP exhibited higher cellular uptake then $4 \mathrm{~nm}$ AuNPs, as demonstrated by total intracellular $\mathrm{Au}$ and total numbers of AuNP per cell (Figure 2A). To visualize the internalized particles and assess their distribution in relation to subcellular compartments, we performed TEM analysis. In TEM images, numerous high electron density-staining particles were observed inside the cells treated with AuNPs (Figure 2C and 2D). Clusters of dark small sized granules were also observed in control cells that were not exposed to AuNP (Figure 2B). However these granules exhibited less electron density than particles found in AuNP treated cells and were most likely due to glycogen deposits and ribosome structures within the cytoplasm [58]. In MCF-7 cells incubated with $4 \mathrm{~nm}$ AuNP, clusters of nanoparticles were seen throughout the cytoplasm with the majority of particles trapped within the membranous structures/vesicles (Figure 2C). These structures were found in the proximity of endoplasmic reticulum (ER) and
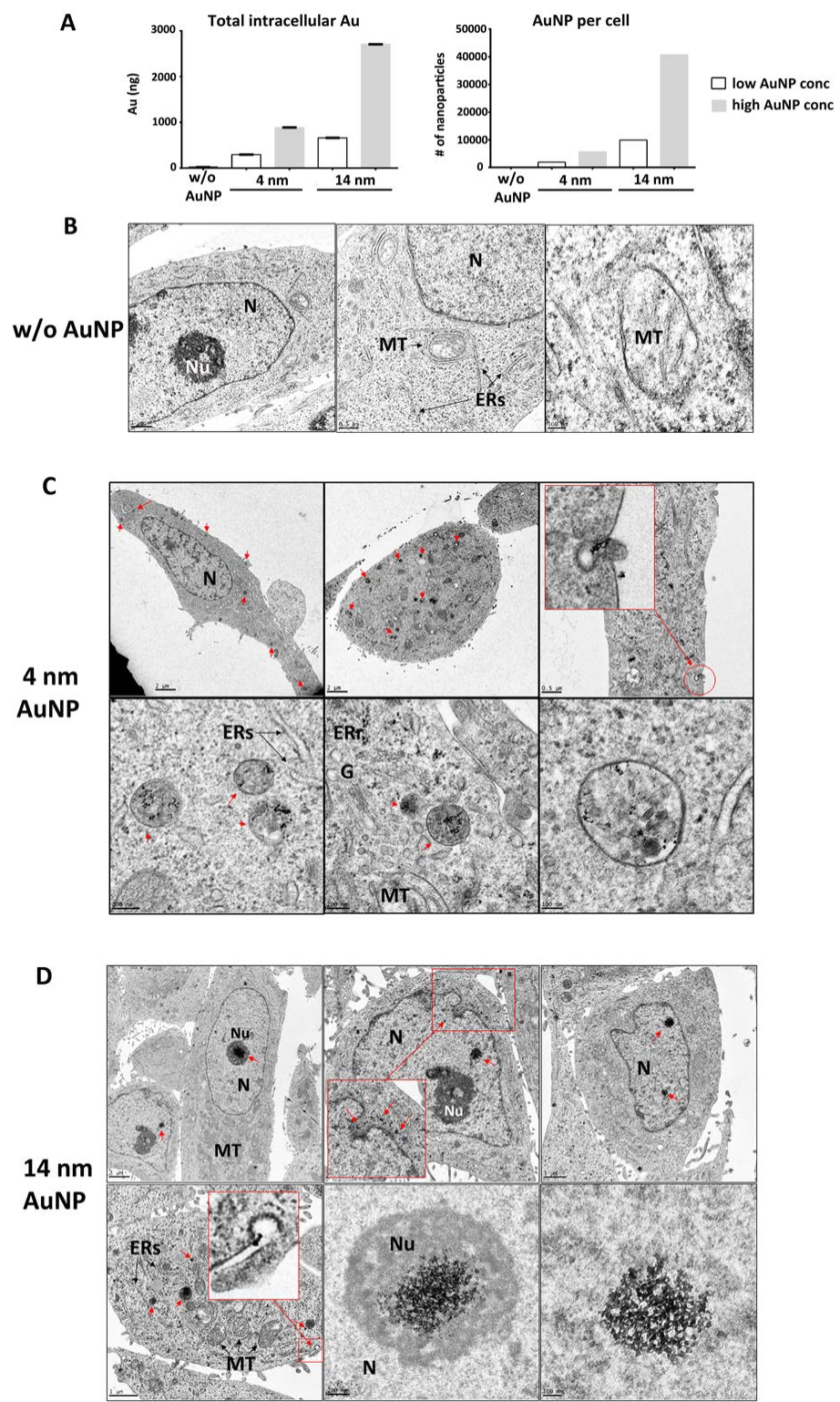

Figure 2: MCF-7 cell uptake of AuNPs. A) Inductively Coupled Plasma Mass Spectrometry (ICP-MS) of intracellular gold in MCF-7 cells after 3 hours of incubation with low and high concentration of $4 \mathrm{~nm}$ and $14 \mathrm{~nm}$ AuNPs. (left panel). Quantification of nanoparticle uptake per cell is shown in right panel. Each bar is presented as mean \pm S.E. B) TEM images of MCF-7 cells not exposed to AuNPs (control) showing a portion of the nucleus (N) with nucleolus (Nu) and the cytoplasm with clearly visible large mitochondria (MT) and smooth endoplasmic reticulum (ERs)(left and middle panel; right panel showing magnified MT structure. C) TEM images of MCF-7 cells exposed to $4 \mathrm{~nm}$ AuNPs showing the internalized high electron density-staining particles inside vesicles (red arrows; top left and middle panels and bottom panels). Nanoparticle engulfment by cell membrane is shown in top right panel. D) TEM images of MCF-7 cells incubated with 14 nm AuNPs where the majority of AuNPs were found within the nuclei (red arrows; top panels). Nucleolar co-localization with intra-nuclear AuNPs is shown in top left and bottom middle panel. Nanoparticle engulfment by nuclear (top middle panel) and cell membrane (bottom left panel). Some AuNPs were detected inside the cytoplasmic vesicles (red arrows, bottom left panel). 
mitochondria (MT). Magnified images of vesicles containing AuNPs are shown in bottom panels of Figure 2C. Random, cell surface AuNP localization was also observed, with some AuNPs positioned within the convoluted cell membrane processes indicative of engulfment step of an internalization process, presumably endocytosis (Figure $2 \mathrm{C}$, upper right panel). However, $4 \mathrm{~nm}$ AuNPs were not observed in the nuclei. On the other hand, in MCF-7 cells incubated with $14 \mathrm{~nm}$ AuNPs, the majority of AuNPs were found as large aggregates within the nuclei (Figure 2D). These aggregates often co-localized with nucleoli (Figure 2D, upper left and lower middle panel). Some of the AuNPs were also detected in close proximity of the nuclear membrane, in close alignment with the nuclear membrane and within the nuclear membrane invagination, altogether indicative of an engulfment step of AuNPs transport across the nuclear membrane (Figure 2D, upper middle panel). Fourteen nm AuNPs were also found within the vesicles inside the cytoplasm, but to a less extent compared to $4 \mathrm{~nm}$ AuNPs (Figure 2D, lower left panel). Random $14 \mathrm{~nm}$ AuNPs also exhibited engulfment by cellular membrane convolutions (Figure 2D, lower left panel). Altogether, TEM data demonstrated MCF7 cellular uptake of AuNPs with nanoparticle size differential intracellular localization. TEM data also revealed that intracellular AuNPs deposits did not affect MCF-7 cell morphology as shown by unremarkable subcellular compartments indicative of a healthy, metabolically active cell system [59].

\section{Effect of AuNPs on MCF-7 cell viability after irradiation}

We aimed to determine the effect of $4 \mathrm{~nm}$ and $14 \mathrm{~nm}$ AuNPs on breast cancer MCF-7 cells proliferation and response to radiation.
First, we performed a dose response experiment to determine if AuNPs had any effect on MCF-7 cells proliferation. Cells were incubated for 3 hours at 4 different concentrations with $4 \mathrm{~nm}$ and $14 \mathrm{~nm}$ AuNPs. Cells were then allowed to grow for 3 and 7 days, at which point cellular respiration, as an indicator of viable cell numbers, was determined by MTT assay [56]. Our data showed that AuNPs alone had no significant effect on MCF7 cell proliferation and the observed differences were well within the experimental error and were not AuNPs concentration or size dependent (Figure 3A and 3B). Hence, for further evaluation of AuNPs ability to sensitize MCF-7 to irradiation we used a single AuNP concentration, $3.12 \times 10^{13} \mathrm{p} / \mathrm{ml}$ for $4 \mathrm{~nm}$ AuNP and $7.2 \times 10^{11} \mathrm{p} / \mathrm{ml}$ for $14 \mathrm{~nm}$ AuNP. After $3 \mathrm{~h}$ incubation with AuNPs, cells were irradiated with 4 Gy dose using $160 \mathrm{kV}, 2.5$ FFF MV or 10FFF MV energies. Seven days later proliferation was analyzed by MTT assay. Significant enhancement of irradiation induced decrease in proliferation was observed at all irradiation energies only with $4 \mathrm{~nm}$ AuNP (Figure 3C), while with $14 \mathrm{~nm}$ AuNP significance was observed only at higher, 2.5 $\mathrm{MV}$ and $10 \mathrm{MV}$ energies used (Figure 3D). This data indicated that the magnitude of demonstrated AuNP radio-sensitization effect in MCF-7 cells may depend on AuNP size and irradiation energy. It also supported the data from our earlier experiment that showed a lack of significant AuNP induced cytotoxicity in MCF-7 cells in the absence of radiation (Figure $3 \mathrm{~A}$ and $3 \mathrm{~B}$ ).

AuNP effect on irradiation induced double strand DNA break

Exposure of cells to ionizing irradiation leads to DNA damage,
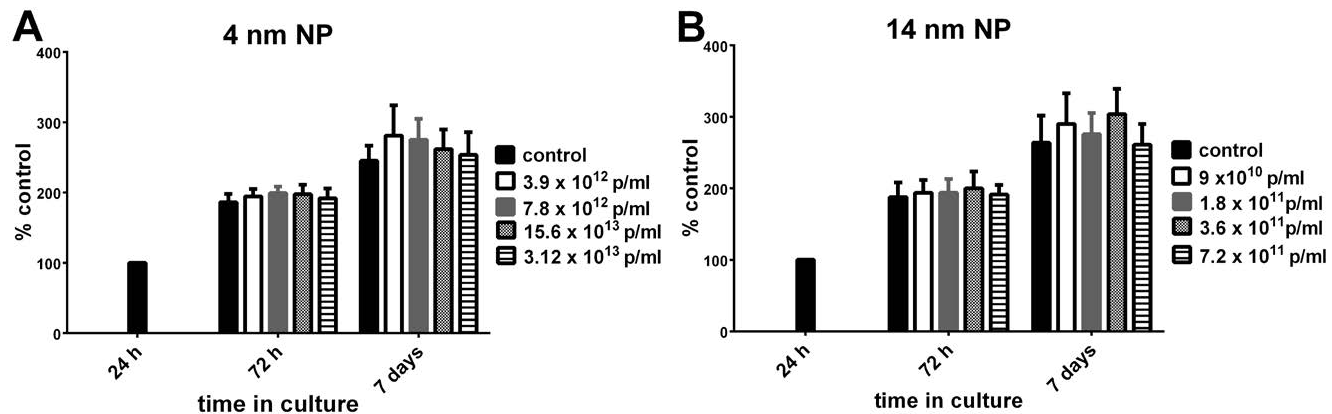
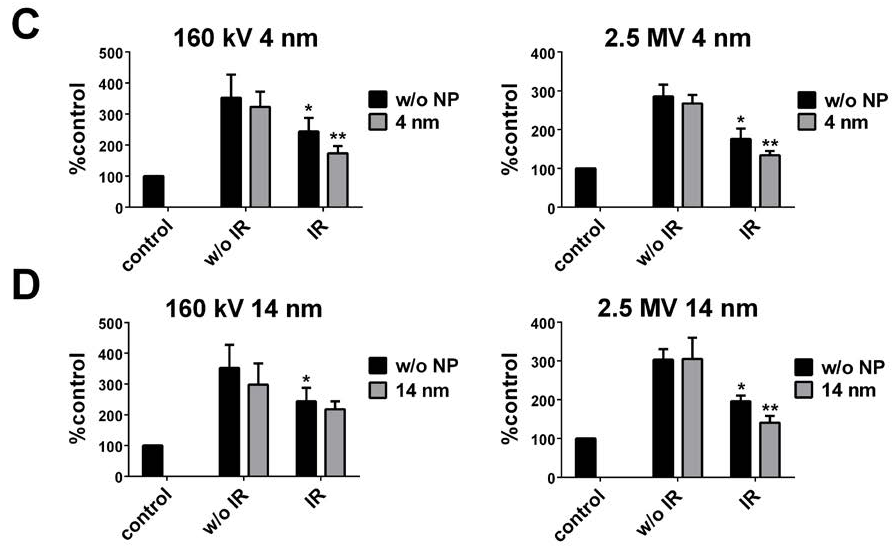
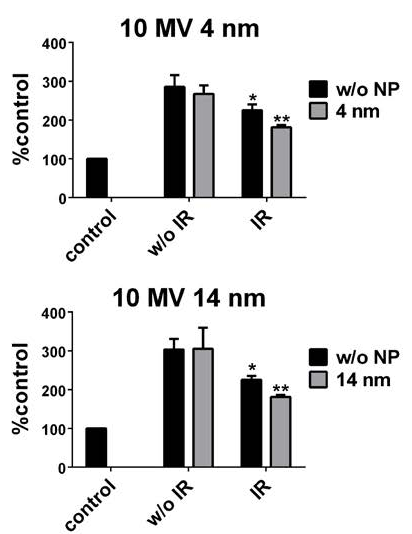

Figure 3: Effect of AuNPs on cell proliferation (A, B) Cell growth activity in non-irradiated MCF-7 cells measured by MTT $72 \mathrm{~h}$ and 7 days after $3 \mathrm{~h}$ incubation with increasing concentrations of (A) $4 \mathrm{~nm}$ AuNPs and (B) $14 \mathrm{~nm}$ AuNPs Cell growth activity in irradiated MCF-7 cells measured by MTT 7 days after irradiation with 4 Gy dose at $160 \mathrm{kV}, 2.5 \mathrm{MV}$ and $10 \mathrm{MV}$. Before irradiation cells were incubated for $3 \mathrm{~h}$ incubation with (C) $3.12 \times 10^{13} \mathrm{p} / \mathrm{ml}$ of $4 \mathrm{~nm} \mathrm{AuNPs}$ and (D) $7.2 \times 10^{11} \mathrm{p} / \mathrm{ml}$ of 14 $\mathrm{nm}$ AuNPs. AuNPs concentration expressed as particles $/ \mathrm{ml}(\mathrm{p} / \mathrm{ml})$. Percentage of viable cells calculated as a percent of basal growth measured at $24 \mathrm{~h}$ and set as $100 \%$. Each bar is presented as mean \pm S.E. $(n=3) .{ }^{*} p<0.05$ vs. w/o IR w/o NP; ${ }^{* *} p<0.05$ vs. IR w/o NP. 
with DNA double strand breaks (DSBs) being the most toxic that can lead to apoptosis. Intracellular deposition of gold NP can potentiate this effect. Here we measured the potential $4 \mathrm{~nm}$ or $14 \mathrm{~nm}$ AuNP to increase DNA histone protein $\mathrm{H} 2 \mathrm{AX}$ phosphorylation $(\gamma \mathrm{H} 2 \mathrm{AX})$, as an indicator of DNA DSBs. We analyzed the H2AX phosphorylation at three photon energies. MCF-7 cells were incubated with either $4 \mathrm{~nm}$ $\left(3.12 \times 10^{13} \mathrm{p} / \mathrm{ml}\right)$ or $14 \mathrm{~nm} \mathrm{AuNP}\left(7.2 \times 10^{11} \mathrm{p} / \mathrm{ml}\right)$ and irradiated with 2 , 4 or 8 Gy using $160 \mathrm{kV}, 2.5 \mathrm{FFF}$ MV (60 MU/min) or $10 \mathrm{FFF}$ MV (2400 MU/min) X-rays. Percent of cells positive for $\gamma \mathrm{H} 2 \mathrm{AX}$ was determined by flow cytometry by analyzing 100000 live cells (gate P1). In addition, cells positive for $\gamma \mathrm{H} 2 \mathrm{AX}$ were further gated to identify a subpopulation exhibiting brighter (gate P2) and dimmer (gate P3) fluorescence intensity. Irradiation alone using $160 \mathrm{kV}, 2.5 \mathrm{FFF}$ MV or $10 \mathrm{FFF} \mathrm{MV}$ induced an increase in the percentage of $\gamma \mathrm{H} 2 \mathrm{AX}$ positive cells that was irradiation dose dependent, and was manifested as an increase in FITC fluorescence exhibited as a shift to the right on histogram plots with a clearly defined increase in bright (green; P2) and dimmer (blue; P3) subpopulation. The dynamics of fluorescence changes could also be monitored on SSC vs. FSC dot plots exhibited as a change in the distribution and ratio of green (P2) vs. blue (P3) cells. At all three energies used, pretreatment with AuNP resulted in an increase in a population of $\gamma \mathrm{H} 2 \mathrm{AX}$ positive cells, compared to their respective controls that were exposed to irradiation only (Figures 4-6). However, the patterns of changes were slightly different between cells treated with 4 and $14 \mathrm{~nm}$ AuNP and it also differed with energies and doses used for irradiation. At $160 \mathrm{kV}$ pretreatment with $14 \mathrm{~nm}$ AuNP resulted in higher percentage of $\gamma \mathrm{H} 2 \mathrm{AXp}$ positive cells at all three doses of irradiation (2, 4 and 8 Gy). This effect was accompanied with a change within P2 and P3 gates and in the FCS and SSC characteristics of the cells, signifying potential changes in cell morphology (Figure 4A and 4B). At the same energy, cells pretreated with $4 \mathrm{~nm}$ AuNP exhibited the same pattern of changes except that treatment with 2 Gy resulted in only a slight increase in the percentage of $\gamma \mathrm{H} 2 \mathrm{AX}$ positive cells. Nevertheless, these $\gamma \mathrm{H} 2 \mathrm{AXp}$ positive cells still exhibited prominent increases within the P2 gate and FCS and SSC characteristics, compared to their respective irradiated controls (Figure $4 \mathrm{C}$ and $4 \mathrm{D}$ ). The lowest $2 \mathrm{~Gy}$ dose irradiation resulted in an appearance of clearly defined shoulder seen on FITC fluorescence histograms that was potentiated with AuNP pretreatment, indicating an increase in number of cells with brighter fluorescence intensity due to H2AX phosphorylation (Figure 4B and 4D). Interestingly, this effect was more pronounced in cells treated with $4 \mathrm{~nm}$ AuNP then in cells treated with $14 \mathrm{~nm}$ AuNP and it seemed to dissipate at the higher doses.

Similarly to the results observed at $160 \mathrm{kV}$, when $2.5 \mathrm{MV}$ was used pretreatment with $14 \mathrm{~nm}$ and $4 \mathrm{~nm}$ AuNP resulted in a higher percentage of $\gamma \mathrm{H} 2 \mathrm{AXp}$ positive cells at all three doses of irradiation (2, 4 and 8 Gy) (Figure 5A-5D). This effect was the least pronounced in cells receiving 2 Gy and $14 \mathrm{~nm}$ AuNP (Figure 5A, top panel). Again, as seen with $160 \mathrm{kV}$, the increase in percentage of $\gamma \mathrm{H} 2 \mathrm{AXp}$ positive cells (P1) was accompanied with an increase in P2 and P3 gates and by changes in the FCS and SSC characteristics of the cells and this was observed with both 14 and $4 \mathrm{~nm}$ AuNPs with all three irradiation doses applied (2, 4 and $8 \mathrm{~Gy})$, but it was most pronounced in cells receiving 2 Gy and $4 \mathrm{~nm}$ AuNPs (Figure 5C, top panel). Remarkably, at 2.5 MV irradiation also resulted in an appearance of clearly defined shoulder on FITC fluorescence histograms that was potentiated with AuNP pretreatment, and was once again, more pronounced in cells treated with $4 \mathrm{~nm}$ AuNP then in cells treated with $14 \mathrm{~nm}$ AuNP.

At $10 \mathrm{MV}$ energy, enrichment in $\gamma \mathrm{H} 2 \mathrm{AXp}$ positive cells with addition of $14 \mathrm{~nm}$ AuNPs was detected at all three doses used, but the most pronounced effect was observed at 4 Gy dose, manifested as an increase in the percentage of $\gamma \mathrm{H} 2 \mathrm{AXp}$ positive cells (P1) as well as the change in P2 and P3 (green and blue) gates (Figure 6A and 6B). Very similar results were observed when $4 \mathrm{~nm}$ AuNP were used (Figure 6D and $6 \mathrm{C}$ ). However, with both 4 and $14 \mathrm{~nm}$ AuNP the increase in the percentage of $\gamma \mathrm{H} 2 \mathrm{AXp}$ positive cells was the least pronounced with the dose of 8 Gy. Irradiation induced shoulder on FITC fluorescence histograms was again clearly potentiated with AuNP pretreatment and this effect was more pronounced with $4 \mathrm{~nm}$ AuNP. Altogether, these data indicate that AuNPs enhanced irradiation induced DNA DSBs in MCF7 cells with the most consistent effect at the dose of 4 Gy at all three energies used that was independent of nanoparticle size. Flow cytometry data is summarized in Table 1 .

\begin{tabular}{|l|c|c|c|}
\hline \multirow{2}{*}{1 R energy } & IR dose & $\mathbf{4} \mathbf{~ n m}$ & $\mathbf{1 4} \mathbf{~ n m}$ \\
\hline \multirow{3}{*}{$160 \mathrm{kV}$} & $2 \mathrm{~Gy}$ & $4 \%$ & $43 \%$ \\
\hline \multirow{3}{*}{$2.5 \mathrm{MV}$} & $4 \mathrm{~Gy}$ & $30 \%$ & $35 \%$ \\
\cline { 2 - 4 } & $8 \mathrm{~Gy}$ & $35 \%$ & $46 \%$ \\
\hline \multirow{3}{*}{$10 \mathrm{MV}$} & $2 \mathrm{~Gy}$ & $49 \%$ & $10 \%$ \\
\cline { 2 - 4 } & $4 \mathrm{~Gy}$ & $27 \%$ & $20 \%$ \\
\hline \multirow{3}{*}{} & $8 \mathrm{~Gy}$ & $13 \%$ & $21 \%$ \\
\hline
\end{tabular}

Table 1: Percentage of cells positive for phosphorylated H2AX determined by flow cytometry.

\section{Discussion}

In the past decades significant advancements has been made in our understanding of breast cancer biology that has profoundly affected current treatment paradigms. However, presently available strategies for breast cancer treatment that rely on irradiation, chemotherapy and surgery, still lack specificity towards cancer cells and are associated with significant toxicity. Nanotechnology, as an emerging discipline, offers a platform for overcoming these and many other challenges associated with breast cancer treatment by introducing engineered nanomaterials that can be used to modify cancer cells responses to the applied therapies. In particular, application of gold nanoparticles as radiation sensitizers have drawn tremendous interest and have been focus of an extensive investigation in past years. However, despite convincing theoretical models and experimental validation, clinical translation to radiation protocols is missing due to insufficient understanding of the mechanisms behind AuNPs biological uptake and radiation sensitization. The inconclusiveness of extensive amount of data on these mechanisms largely stem from a wide range of AuNPs sizes, shapes and preparations as well as the biological systems studied. Despite many research efforts using various in vitro systems, little is known about the effects of AuNP in breast cancer cells. In the present study we optimized the conditions for 4 and $14 \mathrm{~nm}$ AuNPs cellular uptake that achieved significant radio sensitization of MCF-7 breast cancer cells exposed to the therapeutic X-rays at a range of different energies. Protocols designed for $10 \mathrm{MV}$ are clinically relevant and widely used and 2.5 MV has recently been introduced to the Varian TrueBeam Linac. At the same time recent work reported promising results using $6 \mathrm{MV}$ in breast and cervical cancer cell lines [28,47,60], therefore in this study we opted to explore AuNP radiosensitization properties using $2.5 \mathrm{MV}$ and $10 \mathrm{MV}$ and bench mark it against the 160 $\mathrm{kV}$ energy.

One of the important aspects in identifying the optimal and clinically relevant AuNPs formulations is the size and shape of nanoparticle. In vivo bio-distribution and associated toxicity are 
A

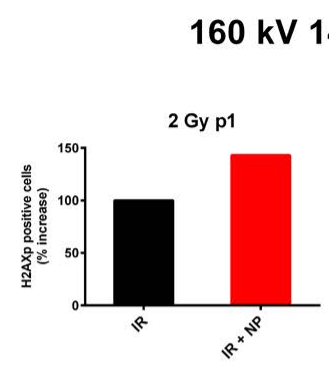

4 Gy p1
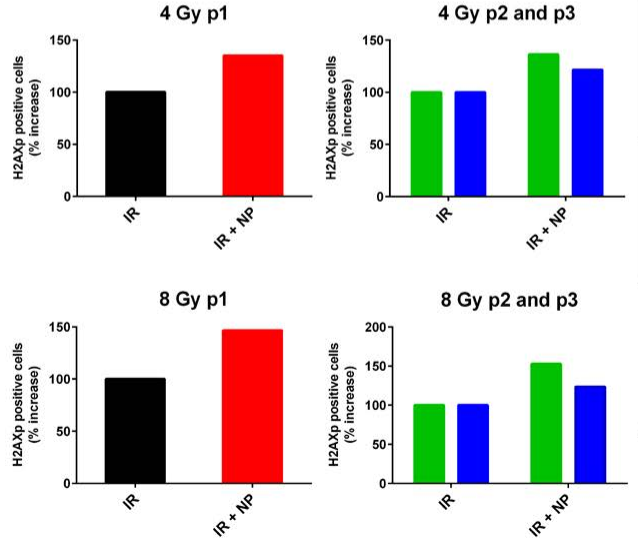

C

$160 \mathrm{kV} 4 \mathrm{~nm}$ AuNP
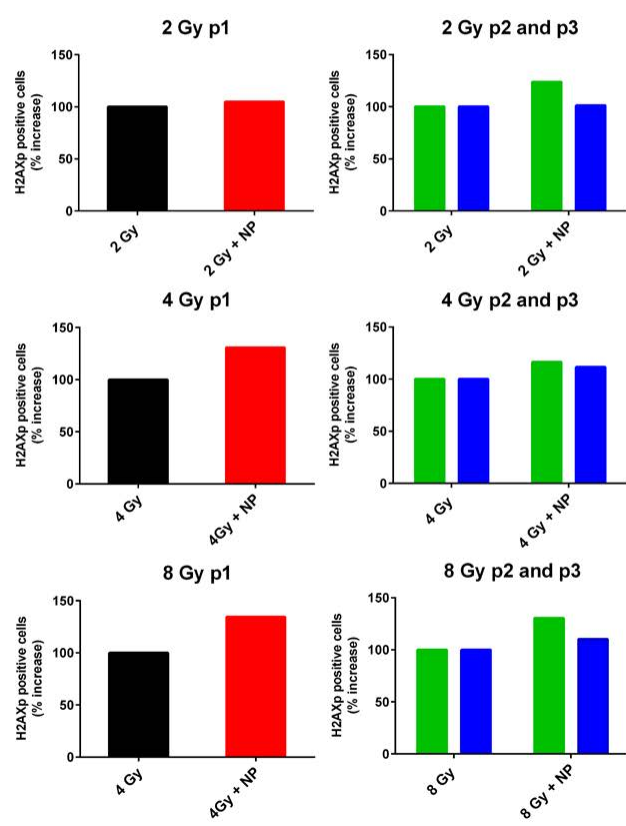

B

D

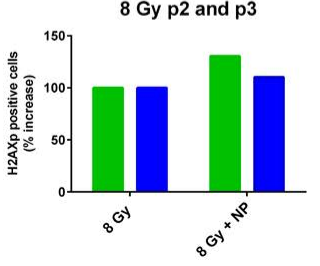

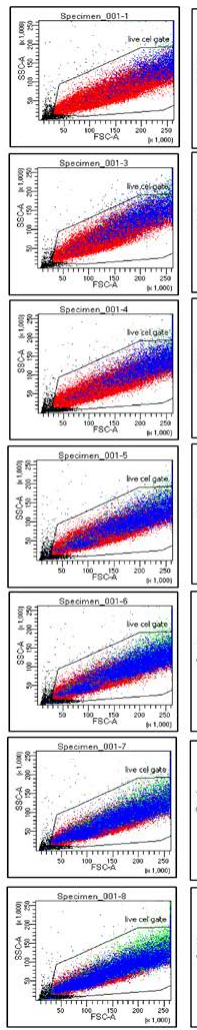

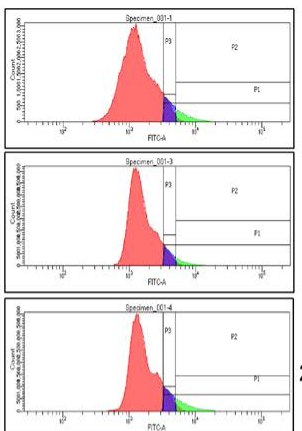

W/o IR

w/o NP

2 Gy w/o NP

$2 \mathrm{~Gy}+14 n m N P$

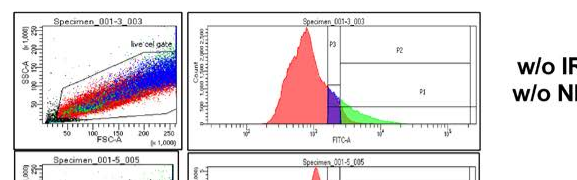

2 Gy w/o NP

$2 \mathrm{~Gy}+4 \mathrm{~nm} N \mathrm{~N}$

4 Gy w/o NP

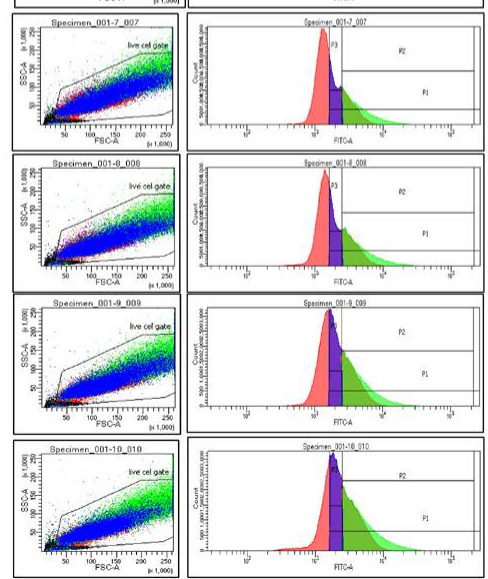

$4 \mathrm{~Gy}+4 \mathrm{~nm} N \mathrm{P}$

8 Gy w/o NP

\section{$8 \mathrm{~Gy}+4 \mathrm{~nm}$ NP}

Figure 4: Flow cytometry analysis of H2AXp in MCF-7 cells exposed to $160 \mathrm{kV}$ X-ray photons. The data depicts percentage of cells positive for phosphorylated form of $\mathrm{H} 2 \mathrm{AX}$ histone DNA protein. Percent increase in cells positive for $\mathrm{H} 2 \mathrm{AXp}$ as determined by gate $\mathrm{p} 1$ and percent change in p2 (green) and p3 (blue) subpopulation within the p1 gate in cells that were prior to irradiation incubated for 3 hours with $14 \mathrm{~nm}$ AuNPs (A) and $4 \mathrm{~nm}$ AuNP (C). Data are expressed as a percent increase relative to the control irradiated cells whose response was set to $100 \%$. Panels B and D show flow cytometric SSC vs. FSC dot plots and FITC fluorescence histograms in cells incubated with $14 \mathrm{~nm}$ AuNPs and $4 \mathrm{~nm}$ AuNP, respectively. At least 100,000 live gated cells were analyzed for FITC-H2AXp expression. Data shown are from one representative experiment. 
A

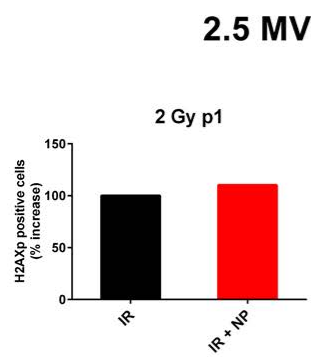

Gy 1

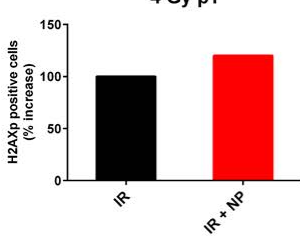

8 Gy p1
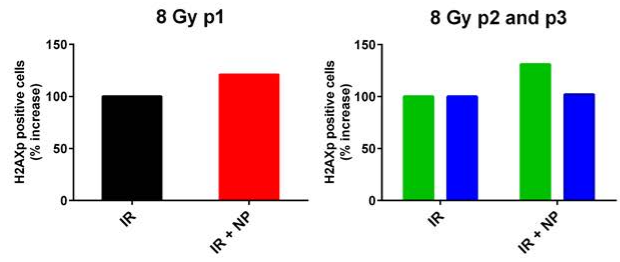

C

\subsection{MV $4 \mathrm{~nm}$ AuNP}
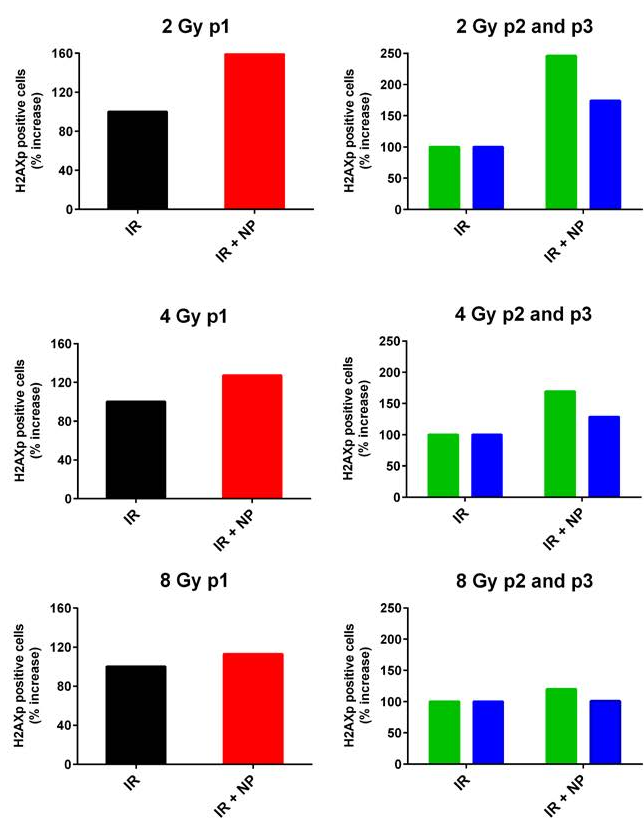

B

D
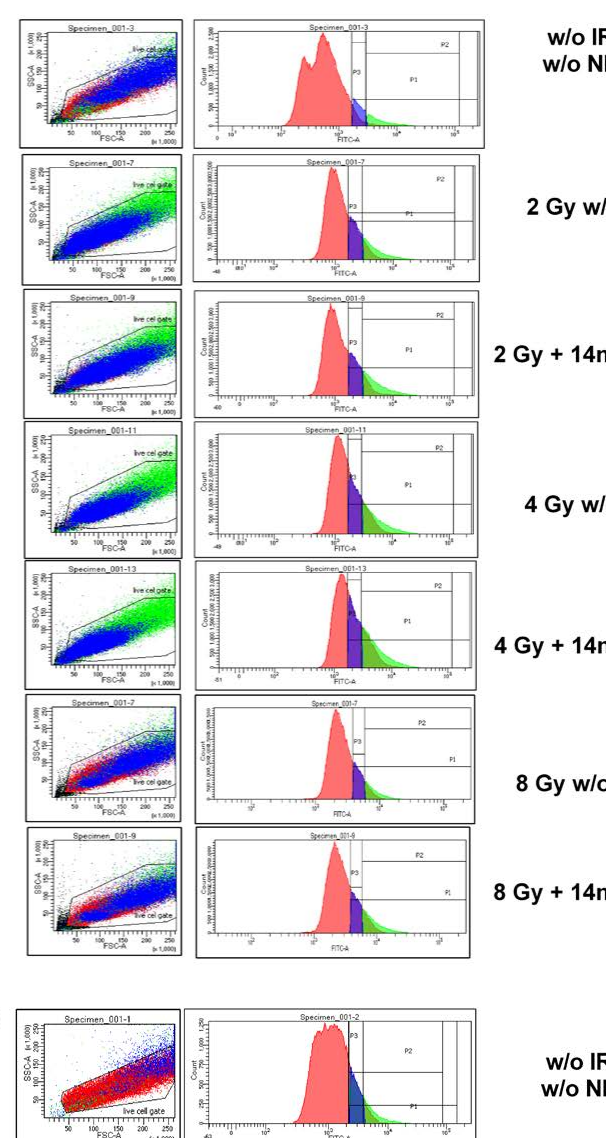

$2 \mathrm{~Gy}+4 \mathrm{~nm} N \mathrm{P}$

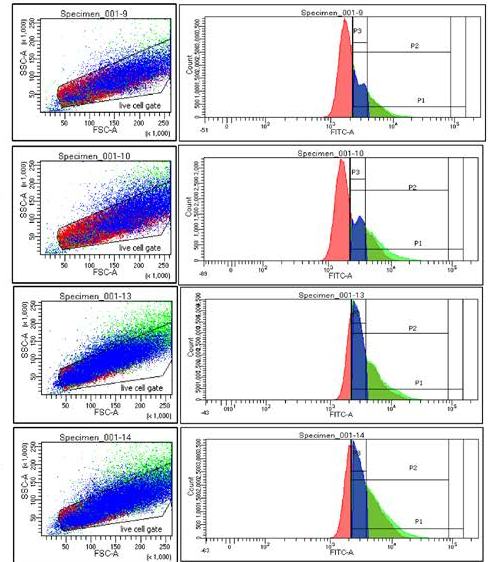

w/o NP

2 Gy w/o NP

4 Gy w/o NP

w/o IR

2 Gy w/o NP

$2 \mathrm{~Gy}+14 \mathrm{~nm}$ NP

4 Gy w/o NP

$4 \mathrm{~Gy}+14 \mathrm{~nm} N \mathrm{P}$

8 Gy w/o NP

$G y+14 n m$ NP

$4 G y+4 n m ~ N P$

8 Gy w/o NP

$8 \mathrm{~Gy}+4 \mathrm{~nm}$ NP

Figure 5: Flow cytometry analysis of H2AXp in MCF-7 cells exposed to $2.5 \mathrm{MV}$ X-ray photons. Percentage of cells positive for phosphorylated form of H2AX histone DNA protein. Percent increase in cells positive for $\mathrm{H} 2 \mathrm{AXp}$ as determined by gate $\mathrm{p} 1$ and percent change in $\mathrm{p} 2$ (green) and $\mathrm{p} 3$ (blue) subpopulation within the $\mathrm{p} 1$ gate in cells that were prior to irradiation incubated for 3 hours with $14 \mathrm{~nm}$ AuNPs (A) and $4 \mathrm{~nm}$ AuNP (C). Data are expressed as a percent increase relative to the control irradiated cells whose response was set to $100 \%$. Panels B and D show flow cytometric SSC vs. FSC dot plots and FITC fluorescence histograms in cells incubated with $14 \mathrm{~nm}$ AuNPs and $4 \mathrm{~nm}$ AuNP, respectively. At least 100,000 live gated cells were analyzed for FITC-H2AXp expression. Data shown are from one representative experiment. 
A

$10 \mathrm{MV} 14 \mathrm{~nm}$ AuNP
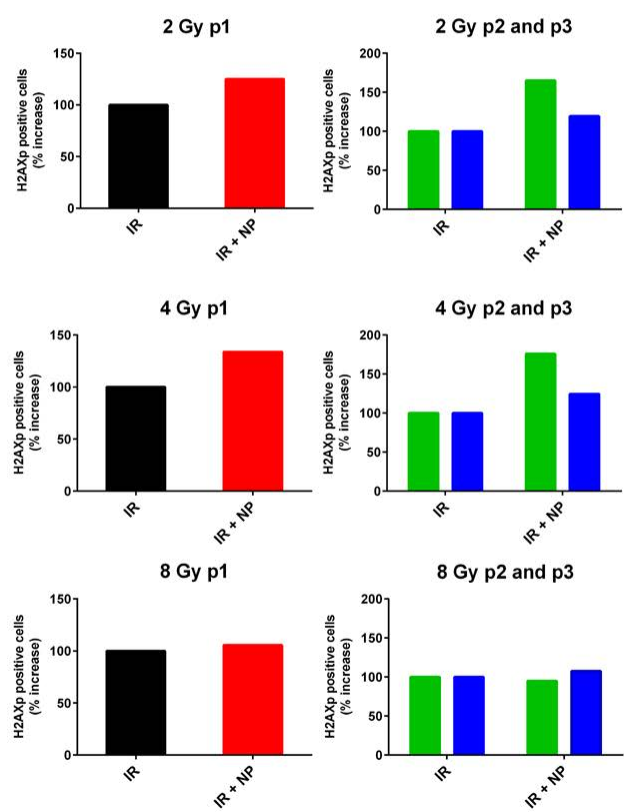

C

10 MV 4 nm AuNP
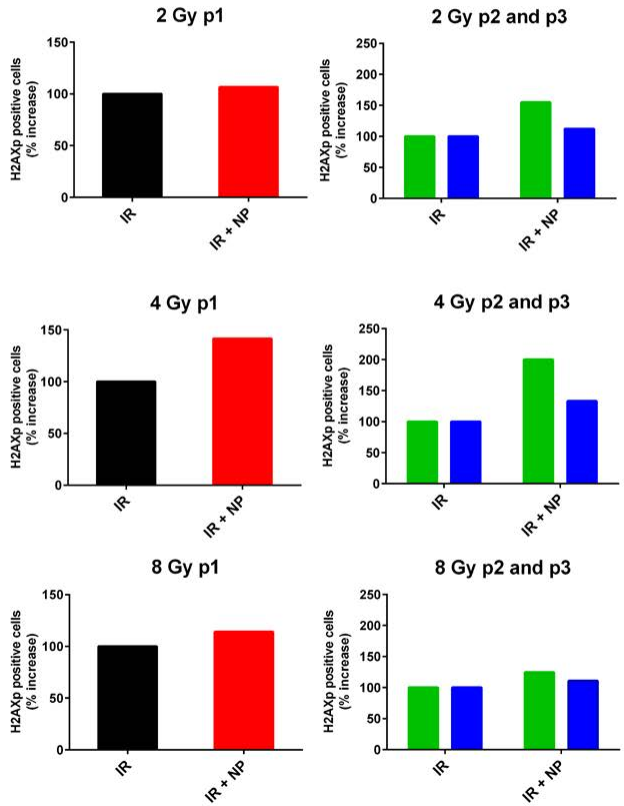

B

D

8 Gy $p 2$ and $p 3$

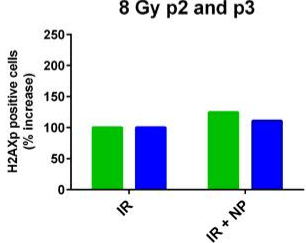

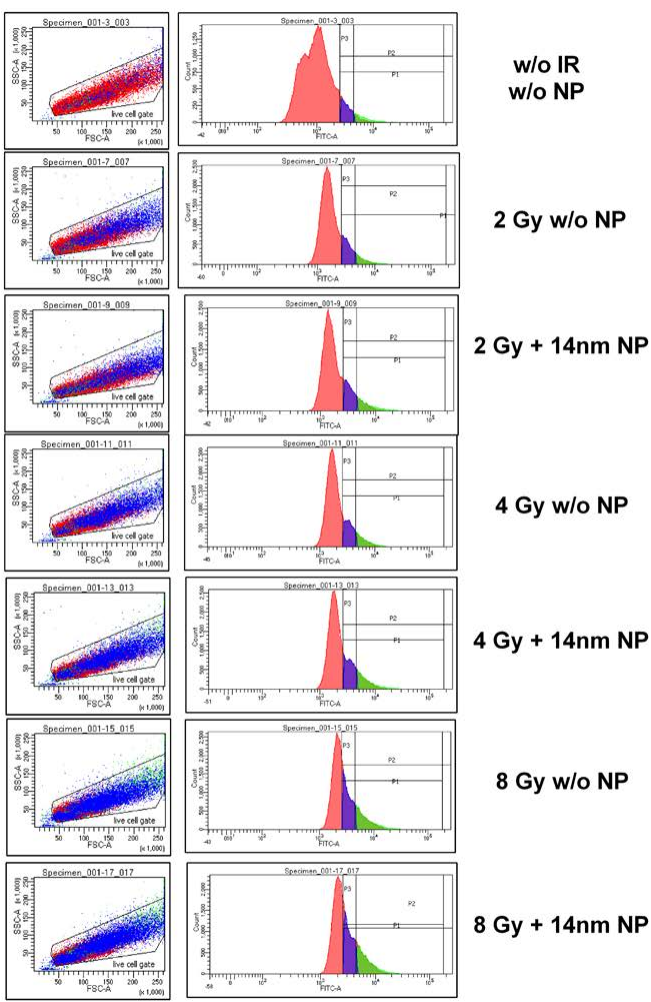
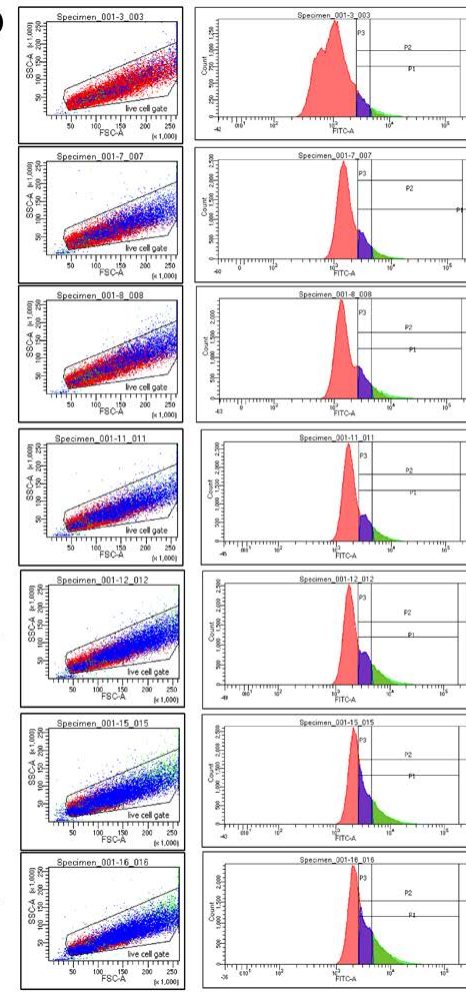

w/o IR

w/o NP

2 Gy w/o NP

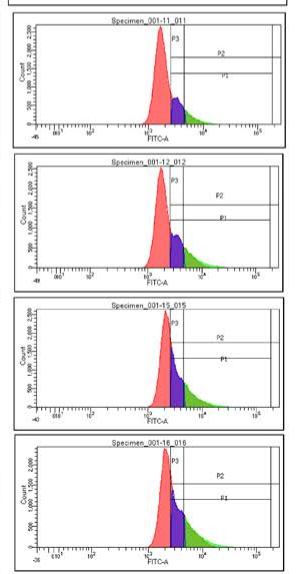

$2 \mathrm{~Gy}+4 \mathrm{~nm} N \mathrm{P}$

4 Gy w/o NP

$4 \mathrm{~Gy}+4 \mathrm{~nm}$ NP

8 Gy w/o NP

$8 \mathrm{~Gy}+4 \mathrm{~nm} \mathrm{NP}$

Figure 6: Flow cytometry analysis of H2AXp in MCF-7 cells exposed to $10 \mathrm{MV}$ X-ray photons. Percentage of cells positive for phosphorylated form of $\mathrm{H} 2 \mathrm{AX}$ histone DNA protein. Percent increase in cells positive for H2AXp as determined by gate p1 and percent change in p2 (green) and p3 (blue) subpopulation within the p1 gate in cells that were prior to irradiation incubated for 3 hours with $14 \mathrm{~nm}$ AuNPs (A) and $4 \mathrm{~nm}$ AuNP (C). Data are expressed as a percent increase relative to the control irradiated cells whose response was set to $100 \%$. Panels B and D show flow cytometric SSC vs. FSC dot plots and FITC fluorescence histograms in cells incubated with $14 \mathrm{~nm}$ AuNPs and $4 \mathrm{~nm}$ AuNP, respectively. At least 100,000 live gated cells were analyzed for FITC-H2AXp expression. Data shown are from one representative experiment. 
usually the main concerns, with larger nanoparticles (>50 $\mathrm{nm}$ ) having a tendency for lower uptake by tumors and probable capture by liver and smaller nanoparticles $(<5.5 \mathrm{~nm})$ being more readily excreted by kidneys [36]. However, cellular uptake is yet another factor to be considered. A majority of studies agree that intermediate size AuNPs $(20-60 \mathrm{~nm})$ exhibit greatest cellular uptake $[36,61]$, while smaller AuNPs $(<5 \mathrm{~nm})$ need to aggregate in order to be endocytosed [36,62]. Considering all these factors we opted to use AuNPs of $4 \mathrm{~nm}$ and $14 \mathrm{~nm}$ in size, both capped by a monolayer of mercaptosuccinic acid (MSA). We showed that both, $4 \mathrm{~nm}$ and $14 \mathrm{~nm}$ size AuNPs were successfully taken up by MCF-7 cells and that their presence itself did not affect cellular morphology or function. While it was postulated that nuclear import through the nuclear pore complex is likely with nanoparticles with diameters of less than $30 \mathrm{~nm}$ [63] with non-targeted, passive diffusion limited to particles smaller than $9 \mathrm{~nm}$ [64], in our study 4 $\mathrm{nm}$ AuNPs did not enter the nuclei and were found in cytoplasm only. These results were unexpected, but it is possible that aggregation of 4 $\mathrm{nm}$ AuNPs resulted in complexes incompatible with nuclear transport. Surprisingly, $14 \mathrm{~nm}$ size AuNPs not only entered the nucleus, but co-localized with nucleoli. In addition, our TEM images capturing engulfment of AuNPs by membranous structures strongly support the involvement of active vesicular transport in AuNPs passage across cellular and nuclear membranes. Although very limited number of studies explored AuNPs application in breast cancer cell lines, our data is in agreement with few reports showing uptake of $10.8 \mathrm{~nm}$ "naked" AuNPs and 15.6 nm PEG modified AuNPs in MCF-7 cell line $[25,38]$. Given that particular intracellular AuNPs localization as well as proximity to various organelles and compartments may govern the type and magnitude of AuNPs modification of cellular responses to stress such as ionizing irradiation, our findings that 14 $\mathrm{nm}$ AuNPs co-localized with nucleoli within the cell nuclei may open a new line of investigation in an effort to link the AuNPs induced radiosensitization and changes at subcellular and molecular level. Designing AuNPs capable of nuclear and/or nucleolar localization may enable full exploitation of physical, chemical and biological mechanisms implicated in AuNPs radiation enhancement effect [65]. Kodiha et al. recent work in MCF-7 breast cancer cells demonstrated that $15.6 \mathrm{~nm}$ PEG modified AuNPs, in addition to entering the nucleus, altered the distribution and function of nucleolar and nuclear proteins important in cancer cell survival, proliferation and metabolism and these changes were significantly enhanced with heat stress $[38,66]$. However, it is not known if similar mechanisms take place in irradiation induced stress. Nevertheless, the significance of our results on AuNPs co-localization with nucleoli is highlighted by the fact that nucleoli hypertrophy due to an increase in ribosome production is typical of many cancer cells [67] and it correlates with tumor malignancy, especially in breast cancer $[68,69]$.

In a majority of previous studies in breast cancer in vitro and in vivo models AuNPs radio- sensitization effect was demonstrated at $\mathrm{kV}$ energies only. Spherical $1.9 \mathrm{~nm}$ AuNPs significantly improved the survival rate in mice bearing mammary EMT- 6 tumors when exposed to $250 \mathrm{kv}$ X-rays [24] and it reduced the survival of MDA-MB-231 breast cancer cells irradiated with $160 \mathrm{kV} \mathrm{X}$-rays [28]. In vitro studies also showed that $10.8 \mathrm{~nm}$ size AuNPs significantly reduced the viability of MCF-7 breast cancer cells exposed to $160-200 \mathrm{kV}$ x-rays $[25,70]$. In agreement with these studies, our data showed that at $160 \mathrm{kV}$ energy AuNPs decreased the proliferation of irradiated MCF-7 breast cancer cells. But, the significance was observed only with $4 \mathrm{~nm}$ AuNPs. While decreased cell proliferation was still detected in cells treated with 14 $\mathrm{nm}$ AuNPs, the reasons behind the lack of significance are unclear and require further investigation. However, $\mathrm{kV}$ energies are rarely used for therapeutic purposes due to the inability to penetrate deep into the body without excessive deposition to the skin and subcutaneous tissues. The majority of cancer radiation treatments rely on MV radiation protocols. Unfortunately, therapeutic radio sensitizing potential of AuNPs at clinically relevant MV energies is still controversial due to the discrepancies between theoretical models and very diverse experimental data [71]. Here we showed that at 2.5 MV and $10 \mathrm{MV}$ photon energies, both $4 \mathrm{~nm}$ and $14 \mathrm{~nm}$ AuNPs induced a significant decrease in MCF-7 cell proliferation. Similarly to our results, modified thio-glucose bound AuNPs induced decrease in MCF-7 cell proliferation exposed to $6 \mathrm{MV}$ [60]. In a different, MDA-MB-231 breast cancer cell line Jain et al. demonstrated AuNPs radio-sensitization at $6 \mathrm{MV}$ and $15 \mathrm{MV}$ photon energies[28]. Radio sensitization at MV energies has also been reported in few other cell lines and it has been suggested that AuNPs nanoscale dose effect involving Auger electrons, as well as biological effects such cell cycle impairment or ROS induced cell damage may play a role in the observed effects [72]. However the exact mechanisms behind AuNP dose enhancement in MV range are still elusive and it is not known if they may be cell specific.

Nuclear DNA has been considered as primary target of ionizing radiation, with DSBs being the most harmful damage. However, ionizing radiation induced cytotoxic pathways may be initiated at other cellular compartments such as mitochondria and nuclei [66,73]. Early post irradiation DNA damage seemed to be directly linked to intracellular/ perinuclear AuNPs presence at the time of irradiation [74], while the late post irradiation damage was suggested to be related to the biological mechanisms of AuNPs actions, predisposing cells to detrimental irradiation effects [72]. Many commonly used radio sensitizers enhance DNA damage by increasing DNA DSBs or inhibiting DNA repair [75]. In this work we studied the phosphorylation of H2AX, as it has previously been reported as a reliable marker for irradiation induced DNA DSBs in MCF-7 cells [76]. Here we showed that both $4 \mathrm{~nm}$ and $14 \mathrm{~nm}$ AuNPs increased radiation induced DNA DSBs. This effect was detected at both $\mathrm{kV}$ and $\mathrm{MV}$ energies used, but with most consistent changes when dose of $4 \mathrm{~Gy}$ was applied. While with $2 \mathrm{~Gy}$ dose changes were not consistent, the 8 Gy dose increased the DNA DSBs at 160 $\mathrm{kV}$ and 2.5 MV while at high $10 \mathrm{MV}$ energy no effect was detected. It is possible that at high $10 \mathrm{MV}$ using the highest $8 \mathrm{~Gy}$ dose already reaches the plateau in induced damages. This finding may carry clinical significance by introducing the possibility of achieving therapeutic enhancement at a lower dose when using high energies. Interestingly, we have not detected significant effect differences between $4 \mathrm{~nm}$ and 14 $\mathrm{nm}$ AuNPs. Since we were looking at the early post irradiation damage $(<1 \mathrm{~h}$ post irradiation) the size related differences may not have been transparent. However, nuclear localization of $14 \mathrm{~nm}$ AuNPs opens the possibility for late post irradiation DNA damage as well. Contrary to our results, a study on MDA-MB-231 breast cancer cells showed no evidence of AuNPs enhancement of irradiation induced DNA DSBs at $6 \mathrm{MV}$ and $15 \mathrm{MV}$ photon energies and $4 \mathrm{~Gy}$ dose [28]. On the other hand, a study using HeLa cervical cancer cell line irradiated with $6 \mathrm{MV}$ photon energy detected increase in DSBs using $50 \mathrm{~nm}$ AuNPs [47]. These discrepancies indicate possibility of differential contribution of physical, chemical and/or biological AuNPS radio-sensitization mechanisms that maybe cell type specific. Furthermore, it is possible that these mechanisms are intrinsic to cancer cells only, as work by Kong et al. showed AuNPs radio-sensitizing effect in MCF-7 breast cancer cells, but not in normal MCF-10A mammary epithelial cells [25]. 
Citation: Janic B, Liu F, Bobbitt KR, Brown SL, Chetty IJ, et al. (2018) Cellular Uptake and Radio-sensitization Effect of Small Gold Nanoparticles in MCF-7 Breast Cancer Cells. J Nanomed Nanotechnol 9: 499. doi: 10.4172/2157-7439.1000499

\section{Conclusion}

We have generated non-modified AuNPs that demonstrated significant cellular uptake and a selective, size dependent intracellular localization with $4 \mathrm{~nm}$ AuNPs preferentially targeting the cytoplasm and $14 \mathrm{~nm}$ residing in the nucleus. Nanoparticles of both sizes caused radio-sensitization in MCF-7 breast cancer cells with no obvious dependence on the particle size. Radio-sensitization was detected as an increase in radiation induced cell proliferation inhibition and radiation induced short term DNA DSBs and these AuNPs driven events did not exhibit size dependence. However, the difference in intracellular AuNPs localization points to a possible differences in mechanisms involved that may be exploited in further developing targeted AuNPs. Another important finding in this study was that radio sensitization was observed for both $\mathrm{kV}$ and $\mathrm{MV}$ energies, indiscriminate of particle size. Photoelectric effect is considered a major mechanism behind AuNPs effect observed at low energies that has been demonstrated using various AuNPs formulations and sizes. However, predicted low to no AuNPs effect at MV energies contradicted the experimental findings such as ours, showing irradiation effect enhancement with still unexplained mechanisms. This work provides a groundwork for further exploring mechanistic of AuNPs driven events in breast cancer cell lines that may be relevant in developing breast cancer radio therapies with less toxicity and superior treatment modalities with better outcomes. In addition, experimental platform used in this work can be applied as a model for studying mechanisms of AuNPs radio sensitization in cancer types other than breast cancer.

\section{Acknowledgments}

This work was supported by the American Cancer Society grant RSG-15-13701-CCE. The authors would like to thank Dr. Alicia Withrow from the MSU Center for Advanced Microscopy for the assistance with TEM studies and Dr. Ruchira Liyanage from WSU Department of Chemical Engineering and Materials Science for the assistance with AuNP characterization.

\section{Conflict of Interest}

This work was supported in part by a Research Scholar Grant, RSG-15-13701 - CCE from the American Cancer Society and all authors of this manuscrip have no other relevant financial interest or relationship to disclose with regard to the subject matter of this study.

\section{References}

1. Siegel RL, Miller KD, Jemal A (2018) Cancer statistics, 2018. CA: A Cancer Journal for Clinicians 68: 7-30.

2. Atun R, Jaffray DA, Barton MB, Bray F, Baumann M, et al. (2015) Expanding global access to radiotherapy. Lancet Oncol 16: 1153-1186.

3. Rosa S, Connolly C, Schettino G, Butterworth KT, Prise KM, et al. (2017) Biological mechanisms of gold nanoparticle radiosensitization. Cancer Nanotechnology 8: 2

4. Bentzen SM (2006) Preventing or reducing late side effects of radiation therapy: radiobiology meets molecular pathology. Nat Rev Cancer 6: 702-713.

5. Kooy HM, Grassberger C (2015) Intensity modulated proton therapy. The British Journal of Radiology 88: 20150195.

6. Wolff D, Stieler F, Welzel G, Lorenz F, Abo-Madyan Y, et al. (2009) Volumetric modulated arc therapy (VMAT) vs. serial tomotherapy, step-and-shoot IMRT and 3D-conformal RT for treatment of prostate cancer. Radiotherapy and Oncology 93: 226-233.

7. Linam J, Yang LX (2015) Recent developments in radiosensitization. Anticancer Res 35: 2479-2485.

8. Jeremic B, Aguerri AR, Filipovic N (2013) Radiosensitization by gold nanoparticles. Clinical and Translational Oncology 15: 593-601.

9. Zhao Z1, Hu Y, Harmon T, Pentel P, Ehrich M, et al. (2017) Rationalization of a nanoparticle-based nicotine nanovaccine as an effective next-generation nicotine vaccine: A focus on hapten localization. Biomaterials 138: 46-56.
10. Zhao Z, Hu Y, Hoerle R, Devine M, Raleigh M, et al. (2017) A nanoparticlebased nicotine vaccine and the influence of particle size on its immunogenicity and efficacy. Nanomedicine 13: 443-454.

11. Zhao Z, Harris B, Hu Y, Harmon T, Pentel PR, et al. (2018) Rational incorporation of molecular adjuvants into a hybrid nanoparticle-based nicotine vaccine for immunotherapy against nicotine addiction. Biomaterials 155: 165-175

12. Zhao Z, Powers K, Hu Y, Raleigh M, Pentel P, et al. (2017) Engineering of a hybrid nanoparticle-based nicotine nanovaccine as a next-generation immunotherapeutic strategy against nicotine addiction: $A$ focus on hapten density. Biomaterials 123: 107-117.

13. Hu Y, Zhao Z, Ehrich M, Fuhrman K, Zhang C, et al. (2015) In vitro controlled release of antigen in dendritic cells using $\mathrm{pH}$-sensitive liposome-polymeric hybrid nanoparticles. Polymer (Guildf) 80: 171-179.

14. Kwatra D, Venugopal A, Anant S (2013) Nanoparticles in radiation therapy: a summary of various approaches to enhance radiosensitization in cancer Translational Cancer Research 2: 330-342.

15. Janic B, Bhuiyan MP, Ewing JR, Ali MM (2016) pH-Dependent Cellular Internalization of Paramagnetic Nanoparticle. ACS sensors 1: 975-978.

16. Liu Y, Zhang P, Li F, Jin X, Li J, et al. (2018) Metal-based NanoEnhancers for Future Radiotherapy: Radiosensitizing and Synergistic Effects on Tumor Cells. Theranostics 8: 1824-1849.

17. Khalili Fard J, Jafari S, Eghbal MA (2015) A Review of Molecular Mechanisms Involved in Toxicity of Nanoparticles. Adv Pharm Bull 5: 447-454.

18. Coulter JA, Jain S, Butterworth KT, Taggart LE, Dickson GR, et al. (2012 Cell type-dependent uptake, localization, and cytotoxicity of $1.9 \mathrm{~nm}$ gold nanoparticles. International Journal of Nanomedicine 7: 2673-2685.

19. Li J, Li JJ, Zhang J, Wang X, Kawazoe N, et al. (2016) Gold nanoparticle size and shape influence on osteogenesis of mesenchymal stem cells. Nanoscale 8: 7992-8007.

20. Kumar CS, Raja MD, Sundar DS, Gover Antoniraj M, Ruckmani K (2015) Hyaluronic acid co-functionalized gold nanoparticle complex for the targeted delivery of metformin in the treatment of liver cancer (HepG2 cells). Carbohydrate Polymers 128: 63-74

21. Thambi T, Park, JH (2014) Recent advances in shell-sheddable nanoparticles for cancer therapy. J Biomed Nanotechnol 10: 1841-1862.

22. Matsumura $\mathrm{Y}$, Maeda $\mathrm{H}$ (1986) A new concept for macromolecular therapeutics in cancer chemotherapy: mechanism of tumoritropic accumulation of proteins and the antitumor agent smancs. Cancer Res 46: 6387-6392.

23. He C, Chow JCL (2016) Gold nanoparticle DNA damage in radiotherapy: A Monte Carlo study. AIMS Bioengineering 3: 352-361.

24. Hainfeld JF, Slatkin DN, Smilowitz HM (2004) The use of gold nanoparticles to enhance radiotherapy in mice. Phys Med Biol 49: N309-315.

25. Kong T, Zeng J, Wang X, Yang X, Yang J, et al. (2008) Enhancement of radiation cytotoxicity in breast-cancer cells by localized attachment of gold nanoparticles. Small 4: 1537-1543.

26. McMahon SJ, Mendenhall MH, Jain S, Currell F (2008) Radiotherapy in the presence of contrast agents: a general figure of merit and its application to gold nanoparticles. Phys Med Biol 53: 5635-5651.

27. Cho SH (2005) Estimation of tumour dose enhancement due to gold nanoparticles during typical radiation treatments: a preliminary Monte Carlo study. Phys Med Biol 50: N163-173.

28. Jain S, Coulter JA, Hounsell AR, Butterworth KT, McMahon SJ, et al. (2011) Cell-specific radiosensitization by gold nanoparticles at megavoltage radiation energies. International journal of radiation oncology, biology, physics 79: 531-539.

29. Zhang C, Huang P, Bao L, He M, Luo T, et al. (2011) Enhancement of gastric cell radiation sensitivity by chitosan-modified gold nanoparticles. J Nanosci Nanotechnol 11: 9528-9535.

30. Berbeco RI, Korideck H, Ngwa W, Kumar R, Patel J, et al. (2012) DNA Damage Enhancement from Gold Nanoparticles for Clinical MV Photon Beams. Radiation research 178: 604-608.

31. Berbeco RI, Ngwa W, Makrigiorgos GM (2011) Localized dose enhancement to tumor blood vessel endothelial cells via megavoltage X-rays and targeted gold nanoparticles: new potential for external beam radiotherapy. Int J Radiat Onco Biol Phys 81: 270-276. 
Citation: Janic B, Liu F, Bobbitt KR, Brown SL, Chetty IJ, et al. (2018) Cellular Uptake and Radio-sensitization Effect of Small Gold Nanoparticles in MCF-7 Breast Cancer Cells. J Nanomed Nanotechnol 9: 499. doi: 10.4172/2157-7439.1000499

32. Zheng Y, Hunting DJ, Ayotte $P$, Sanche $L$ (2008) Radiosensitization of DNA by gold nanoparticles irradiated with high-energy electrons. Radiat Res 169 : 19-27.

33. Rossi G, Monticelli L (2016) Gold nanoparticles in model biological membranes: A computational perspective. Biochim Biophys Acta 1858: 2380-2389.

34. Chithrani BD, Ghazani AA, ChanWC (2006) Determining the size and shape dependence of gold nanoparticle uptake into mammalian cells. Nano Lett 6 : $662-668$

35. Chithrani BD, Stewart J, Allen C, Jaffray DA (2009) Intracellular uptake, transport, and processing of nanostructures in cancer cells. Nanomedicine 5 : 118-127.

36. Dimitriou NM, Tsekenis G, Balanikas EC, Pavlopoulou A, Mitsiogianni M, et al. (2017) Gold nanoparticles, radiations and the immune system: Current insights into the physical mechanisms and the biological interactions of this new alliance towards cancer therapy. Pharmacol Ther 178: 1-17.

37. Khan JA, Pillai B, Das TK, Singh Y, Maiti S (2007) Molecular effects of uptake of gold nanoparticles in HeLa cells. Chembiochem 8: 1237-1240.

38. Kodiha M, Mahboubi H, Maysinger D (2016) Gold Nanoparticles Impinge on Nucleoli and the Stress Response in MCF7 Breast Cancer Cells. Nanobiomedicine 3: 3.

39. Taylor U, Klein S, Petersen S, Kues W, Barcikowski S, et al. (2010) Nonendosomal cellular uptake of ligand-free, positively charged gold nanoparticles. Cytometry A 77: 439-446.

40. De Jong WH, Hagens WI, Krystek P, Burger MC, Sips AJ, et al. (2008) Particle size-dependent organ distribution of gold nanoparticles after intravenous administration. Biomaterials 29: 1912-1919.

41. Choi HS, Liu W, Misra P, Tanaka E, Zimmer JP, et al. (2007) Renal Clearance of Nanoparticles. Nature biotechnology 25: 1165-1170.

42. Zhang Zhang XD, Wu D, Shen X, Chen J, Sun YM, et al. (2012) Size-dependen radiosensitization of $\mathrm{PEG}$-coated gold nanoparticles for cancer radiation therapy. Biomaterials 33: 6408-6419.

43. Pan Y, Leifert A, Ruau D, Neuss S, Bornemann J, et al. (2009) Gold Nanoparticles of Diameter $1.4 \mathrm{~nm}$ Trigger Necrosis by Oxidative Stress and Mitochondrial Damage. Small 5: 2067-2076.

44. Ott M, Gogvadze V, Orrenius S, Zhivotovsky B (2007) Mitochondria, oxidative stress and cell death. Apoptosis 12: 913-922.

45. Lomax ME, Folkes LK, O'Neill P (2013) Biological consequences of radiationinduced DNA damage: relevance to radiotherapy. Clin Oncol (R Coll Radiol) 25: $578-585$

46. Rogakou EP, Pilch DR, Orr AH, Ivanova VS, Bonner WM (1998) DNA doublestranded breaks induce histone $\mathrm{H} 2 \mathrm{AX}$ phosphorylation on serine 139. J Biol Chem 273: 5858-5868.

47. Chithrani DB, Jelveh S, Jalali F, van Prooijen M, Allen C, et al. (2010) Gold nanoparticles as radiation sensitizers in cancer therapy. Radiat Res 173: 719-728.

48. Albanese A, Tang PS, Chan WC (2012) The effect of nanoparticle size, shape, and surface chemistry on biological systems. Annu Rev Biomed Eng 14: 1-16.

49. Alkilany AM, Murphy CJ (2010) Toxicity and cellular uptake of gold nanoparticles: what we have learned so far? J Nanopart Res 12: 2313-2333.

50. Senut MC, Zhang Y, Liu F, Sen A, Ruden DM, et al. (2016) Size-Dependent Toxicity of Gold Nanoparticles on Human Embryonic Stem Cells and Their Neural Derivatives. Small 12: 631-646.

51. Turkevich J, Stevenson PC, Hillier J (1951) A Study of the Nucleation and Growth Processes in the Synthesis of Colloidal Gold. Discussions of the Faraday Society 11: 55

52. Frens G., (1972) Particle-Size and Sol Stability in Metal Colloids. KolloidZeitschrift and Zeitschrift Fur Polymere 250: 736-741.

53. Frens G (1973) Controlled Nucleation for Regulation of Particle-Size in Monodisperse Gold Suspensions. Nature-Physical Science 241: 20-22.

54. Kimling J, Maier M, Okenve B, Kotaidis V, Ballot H, et al. (2006) Turkevich method for gold nanoparticle synthesis revisited. Journal of Physical Chemistry B 110: 15700-15707.

55. Delgado AV, González-Caballero F, Hunter RJ, Koopal LK, Lyklema J, et al (2005) Measurement and Interpretation of Electrokinetic Phenomena. J Colloid Interface Sci 309: 194-224.
56. Mueller $\mathrm{H}$, Kassack MU, Wiese M (2004) Comparison of the usefulness of the MTT, ATP, and calcein assays to predict the potency of cytotoxic agents in various human cancer cell lines. J Biomol Screen 9: 506-515.

57. Khlebtsov N, Dykman L (2011) Biodistribution and toxicity of engineered gold nanoparticles: a review of in vitro and in vivo studies. Chem Soc Rev 40: 1647 1671.

58. Russo J, Bradley RH, McGrath C, Russo IH (1977) Scanning and Transmission Electron Microscopy Study of a Human Breast Carcinoma Cell Line (MCF-7) Cultured in Collagen-coated Cellulose Sponge. Cancer Res 37: 2004-2014.

59. Beneduci A, Chidichimo G, Tripepi S, Perrotta E (2005) Transmission electron microscopy study of the effects produced by wide-band low-power millimeter waves on MCF-7 human breast cancer cells in culture. Anticancer Res 25 : 1009-13.

60. Soleymanifard S, Rostami A, Aledavood SA, Matin MM, Sazgarnia A (2017) Increased radiotoxicity in two cancerous cell lines irradiated by low and high energy photons in the presence of thio-glucose bound gold nanoparticles. Int $J$ Radiat Biol 93: 407-415.

61. He C, Hu Y, Yin L, Tang C, Yin C (2010) Effects of particle size and surface charge on cellular uptake and biodistribution of polymeric nanoparticles. Biomaterials 31: 3657-3666.

62. Chithrani BD, Chan WCW (2007) Elucidating the Mechanism of Cellular Uptake and Removal of Protein-Coated Gold Nanoparticles of Different Sizes and Shapes. Nano Letters 7: 1542-1550.

63. Berry CC, de la Fuente JM, Mullin M, Chu SW, Curtis AS (2007) Nuclear localization of HIV-1 tat functionalized gold nanoparticles. IEEE Trans Nanobioscience 6: 262-269.

64. Beck M, Förster F, Ecke M, Plitzko JM, Melchior F, et al. (2004) Nuclear pore complex structure and dynamics revealed by cryoelectron tomography. Science 306: 1387-1390.

65. Her S, Jaffray DA, Allen C (2015) Gold nanoparticles for applications in cance radiotherapy: Mechanisms and recent advancements. Adv Drug Deliv Rev 109: 84-101.

66. Kodiha M, Hutter E, Boridy S, Juhas M, Maysinger D, et al. (2014) Gold nanoparticles induce nuclear damage in breast cancer cells, which is further amplified by hyperthermia. Cell Mol Life Sci 71: 4259-4273.

67. Derenzini M, Trerè D, Pession A, Govoni M, Sirri V, et al. (2000) Nucleolar size indicates the rapidity of cell proliferation in cancer tissues. J Pathol 191 181-186.

68. Treré D, Ceccarelli C, Migaldi M, Santini D, Taffurelli M, et al. (2006) Cell proliferation in breast cancer is a major determinant of clinical outcome in nodepositive but not in node-negative patients. Appl Immunohistochem Mol Morpho 14: 314-323.

69. Montanaro L, Trere D, Derenzini M (2880) Nucleolus, ribosomes, and cancer Am J Pathol, 173: 301-310.

70. Butterworth KT, Coulter JA, Jain S, Forker J, McMahon SJ, et al. (2010) Evaluation of cytotoxicity and radiation enhancement using $1.9 \mathrm{~nm}$ gold particles: potential application for cancer therapy. Nanotechnology 21: 295101.

71. Schuemann J, Berbeco R, Chithrani DB, Cho SH, Kumar R, et al. (2016) Roadmap to Clinical Use of Gold Nanoparticles for Radiation Sensitization. Int J Radiat Oncol Biol Phys 94: 189-205.

72. Butterworth KT, McMahon SJ, Taggart LE, Prise KM (2013) Radiosensitization by gold nanoparticles: effective at megavoltage energies and potential role of oxidative stress. Translational Cancer Research 2: 269-279.

73. Prise KM, Schettino G, Folkard M, Held KD (2005) New insights on cell death from radiation exposure. Lancet Oncol 6: 520-528.

74. McQuaid HN, Muir MF, Taggart LE, McMahon SJ, Coulter JA, et al. (2016) Imaging and radiation effects of gold nanoparticles in tumour cells. Scientific Reports 6: 19442.

75. Chen HHW, Kuo MT (2017) Improving radiotherapy in cancer treatment: Promises and challenges. Oncotarget 8: 62742-62758.

76. Paull TT, Rogakou EP, Yamazaki V, Kirchgessner CU, Gellert M, et al. (2000) A critical role for histone H2AX in recruitment of repair factors to nuclear foc after DNA damage. Curr Biol 10: 886-895. 